\title{
Improved Groundnut Performance under Natural Field Leaf Spot and Rosette Mosaic Virus Infections in the South Western Agro-Ecological Zone of Uganda
}

\author{
Peace Kankwatsa $^{1 *}$, Laban Turyagyenda², Maggiore Kyomugisha1 ${ }^{1}$ K. D. Okello ${ }^{3}$ \\ ${ }^{1}$ Mbarara Zonal Agricultural Research and Development Institute, National Agricultural Research Organisation, Mbarara, Uganda \\ ${ }^{2}$ Ngetta Zonal Agricultural Research and Development Institute, National Agricultural Research Organisation, Lira, Uganda \\ ${ }^{3}$ National Semi-Arid Agricultural Research Institute, National Agricultural Research Organisation, Soroti, Uganda \\ Email: ^kankwatsap@gmail.com, labanturyagenda@yahoo.com, maggiore2011@gmail.com, kod143@gmail.com
}

How to cite this paper: Kankwatsa, P., Turyagyenda, L., Kyomugisha, M. and Okello, K.D. (2021) Improved Groundnut Performance under Natural Field Leaf Spot and Rosette Mosaic Virus Infections in the South Western Agro-Ecological Zone of Uganda. Open Access Library Journal, 8: e7200.

https://doi.org/10.4236/oalib.1107200

Received: January 29, 2021

Accepted: May 11, 2021

Published: May 14, 2021

Copyright $\odot 2021$ by author(s) and Open Access Library Inc.

This work is licensed under the Creative Commons Attribution International License (CC BY 4.0).

http://creativecommons.org/licenses/by/4.0/

\begin{abstract}
For farmers to satisfy the food, nutrition and income demands on groundnut in the South Western Agro-Ecological Zone (SWAEZ), the accessibility, and adaptability of economically viable and high performing varietal and non-varietal technologies must increase to enhance production. Field experiments to evaluate the agronomic performance of advanced lines of improved nine AGRA red, nine Spanish and six Serenut varieties were concurrently carried out on-station at the Mbarara Zonal Agricultural Research and Development Institute (MbaZARDI) in Mbarara District, Uganda. The AGRA red and Spanish groundnut lines showed high levels of rosette mosaic disease (GRD) tolerance in the zone. The short AGRA and Spanish lines were highly resistant to leaf spots, while the tall lines were highly susceptible to leaf spots, and not drought tolerant. The late maturing AGRA lines (SGV 99241 and SGV 99046), yielded better than the early maturing lines (SGV 99065 and SGV 99043). The best performing AGRA lines identified for promotion in the zone were SGV 99241, 99046, 99064, 99048, 99019 and 99032. The most leaf spot-resistant Spanish line was ICGV SM 02501, but lines ICGV SM 01514, ICGV SM 03590, ICGV SM 01515 and ICGV SM 01502 displayed varying levels of resistance during the two seasons of 2015. Spanish lines: ICGV SM 01502, ICGV SM 99568, ICGV SM 01504, ICGV SM 01510, ICGV SM 99555, ICGV SM 01514 and ICGV SM 01515 were suitable for growing in the SWAEZ. Spanish lines that were either highly resistant or resistant to groundnut rosette virus disease (GRD), unfortunately, were either moderately-susceptible or susceptible to the leaf spot diseases. Therefore, the tested Spanish lines were only suitable to environments that are prone to GRD but free of the leaf spot pa-
\end{abstract}


thogens. AGRA red lines SGV 99241, SGV 99046, SGV 99064, SGV 99048, SGV 99019 and SGV 99032 were the best performing. Of the Serenut varieties evaluated, Serenut $5 \mathrm{R}$ was early maturing and rosette mosaic virus tolerant. Apart from Serenut 1; Serenut 2, 3R, 4R, 5R and 6T displayed very high levels of tolerance to rosette mosaic virus disease. The combination of moderate resistance (MR)-resistance (R) and high resistance (HR) in the AGRA red lines and Serenut varieties to leaf spots and rosette mosaic virus, respectively, indicated an effective control measure of the major groundnut disease problems in the zone. The integration of moderate-resistance to high disease resistance, high drought tolerance and high yielding potential in several Serenut, AGRA red and Spanish lines can enhance groundnut production if proper agronomic management practices and timely planting are applied.

\section{Subject Areas}

Agricultural Engineering, Agricultural Science

\section{Keywords}

Improved Groundnut, Adaptability, Disease Resistance, Yield and SWAEZ

\section{Introduction}

Groundnut (Arachis hypogea Linn.), globally known as peanut has many desirable characteristics such as high quality protein content [(38.6\%), [1]/(257 g/kg), [2]] for human diet. Groundnut is not only a good source of calcium (Ca), phosphorus $(\mathrm{P})$, iron $(\mathrm{Fe})$, zinc $(\mathrm{Zn})$ and boron $(\mathrm{Bo})$, but it also contains vitamin E, small amounts of vitamin B complex, unsaturated fatty acids, fibre, antioxidants and phytosterols [2], and is high in calories. Being an oil seed crop, it contains $44 \%-56 \%$ of high quality oil content, and low ash contents [1] [3] [4] [5]. Apart from the human dietary attributes, groundnut generates residual nitrogen in the soil, which benefits subsequent crops [6], especially when groundnut residues are incorporated into the soil during ploughing [7] [8] [9] [10]. Because of the high level of unfatted protein (38.6\%), groundnuts are used in production of high quality animal feed [1].

Globally, groundnut is an agronomically and economically important crop grown extensively by millions of small-scale farmers throughout the semi-arid tropics [11] of Asia, Africa and Latin America. It generates employment for various categories of workers for on-farm production, marketing, transportation and processing. Groundnut is currently grown on $27.3-29.6$ million (m) hectares (ha) worldwide with a production range of $44.4-48.8$ million tonnes, and average yield of $1.69 \mathrm{~kg} \cdot \mathrm{ha}^{-1}$ [12] [13]. Production is concentrated in Asia (57.8\%) and Africa (32.2\%), where the crop is grown mostly by smallholder farmers with limited inputs and under rain-fed conditions.

The increased awareness of its nutrition value as a source of protein, oil, fibre, 
vitamins and other useful active compounds, and marketability (high market value) during the last 5 - 10 years, there has been substantial increase in the growing of groundnut as a food crop, but mostly as a non-traditional income generating commodity among the rural farmers in the semi-arid areas of the SWAEZ of Uganda. In this zone, groundnut is the seventh priority crop and second major legume crop after beans [14]. However, mixed seeds of the mostly grown and unidentified landraces adapted more for survival than yield are preserved by farmers from many previous harvests and/or bought from local markets. Yields from such varieties average $700-800 \mathrm{Kg} / \mathrm{ha}$ of dry unshelled pods [15]. The groundnut is mostly grown for income generation due to its high market demand, which has been rising for the last 10 years leading to price increase season after season. Currently, the retail market price of one kilogram of groundnuts is Uganda shillings 6000 (approximately US\$1.6) [16].

Despite the high demand for groundnuts, farmers' yields continue to be lower than the expected yields of $2500-3000 \mathrm{~kg} / \mathrm{ha}$ reported by research. Studies have shown that the low yielding of groundnuts is caused by several factors of which diseases [17] [18] [19] [20], prolonged drought/limited green water [2], continuous use of unimproved and/or degenerated seed [4] and low soil fertility are major. While farmers prefer to grow the local red groundnut varieties due to their high market demand, they are low yielding, late maturing and are highly susceptible to disease especially the leaf spots. Early and late leaf spots caused by (Cercospora arachidcola Hori) and Phaeoisariopsis personata Berk. \& Curtis), respectively, [21] and Rosette mosaic virus [22] [23], are the major diseases causing significant yield losses in the common market-preferred (red-grain) local groundnut varieties. Initial leaf spot symptoms usually develop during the vegetative growth stage ( 4 - 8 weeks after planting) when plants are gaining the canopy that supports pod formation and filling. Severe plant damage occurs after flowering during pod and grain formation, hence leading high yield losses. While the red-grain groundnut varieties are the most preferred, in Western, Central and Southern Uganda [24], they are highly susceptible to leaf spot diseases, and are severely affected by a combination of leaf spot diseases during drought periods. Majority of groundnut farmers in the SWAEZ continue to struggle in production due to disease constraints to which there has been limited research response for developing appropriate control measures. Chemical application is not affordable to most farmers. The current prevailing climatic change, which is characterized by prolonged drought periods, inadequate and un-predictable rainfall patterns have made it difficult for farmers to grow groundnuts thus creating need for adoption and/or adaption of disease and drought tolerant varieties [15] [25] [26] [27] [28].

In order for farmers to satisfy the increasing groundnut demand for food/nutrition and income [29], there is need to increase production by accessing and adopting economically viable and high performing varietal and non-varietal technologies. Although, the National Agricultural Research Organ- 
ization has released several improved groundnut varieties, majority of the farmers are not growing them partly because of lack of accessibility to the good quality seeds [16], and lack of information about their agronomic performance under their farming systems. While the agronomic performance of the improved varieties has been evaluated elsewhere in the country, their performances under the SWAEZ semi-arid conditions and cropping systems have not been validated. Therefore, this research was carried to evaluate the effect of leaf spots and rosette mosaic virus diseases on the agronomic performances of the improved lines/varieties within the SWAEZ, and select the best yielding lines/varieties adaptable to the zone. Assuming that improved groundnut varieties are multi-disease resistant and high yielding compared to local varieties, by the end of this study, the best performing (high yielding, disease and drought tolerant) improved lines/varieties will be identified and selected for promotion in the zone.

\section{Materials and Methods}

Field evaluation experiments of nine AGRA red, nine Spanish and six Serenut lines/varieties were concurrently carried out at the Mbarara Zonal Agricultural Research and Development Institute (MbaZARDI) in Mbarara Uganda located at 1443 meters above sea level (masl), $0^{\circ} 36^{\prime} \mathrm{S}$ and $30^{\circ} 42^{\prime} \mathrm{E}$. The SWAEZ experienced average monthly temperature of $21.9^{\circ} \mathrm{C}, 21.6^{\circ} \mathrm{C}, 21.8^{\circ} \mathrm{C}$, and monthly rainfall of $116.1 \mathrm{~cm}, 90.5 \mathrm{~cm}$ and $132.2 \mathrm{~cm}$ during 2014B, 2015A and 2015B (Figure 1), respectively. The 18 advanced lines and six released varieties of groundnut were kindly provided by Dr. Okello K. David (Groundnut Breeder) at the National Semi Arid Agricultural Research Institute (NaSARRI) based in Soroti District, Eastern Uganda. The three improved groundnut sets of six Serenut, nine AGRA red and nine Spanish lines and one local variety were separately evaluated based on field agronomic parameters for three seasons. Single-factor experiments were setup using the randomized complete block design (RCBD), and replicated four times.

Serenut varieties (Serenut 5R, Serenut 2, Serenut 4T, Serenut 3R, Serenut $6 \mathrm{~T}$ and Serenut $1 \mathrm{R}$ ) and the local check were planted in $3 \mathrm{~m} \times 3 \mathrm{~m}$ plots at a spacing

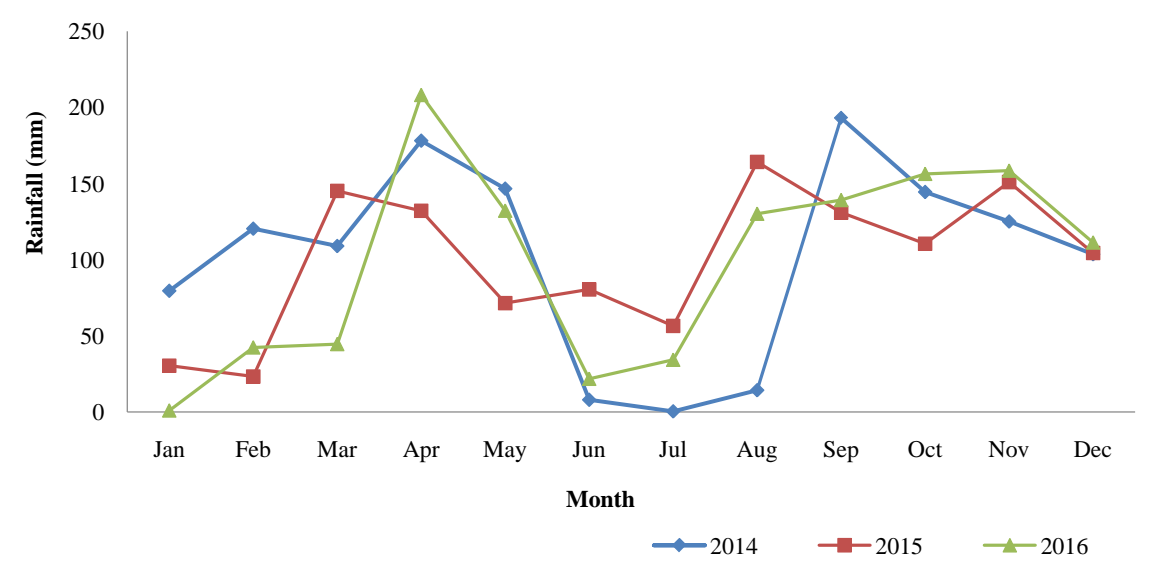

Figure 1. Rainfall distribution across the groundnut cropping seasons of 2014B, 2015A and 2015B in the South Western Agro-Ecological Zone of Uganda. 
of $45 \mathrm{~cm} \times 15 \mathrm{~cm}$ and replicated twice. The AGRA red lines (SGV 99064, SGV 99043, SGV 99019, SGV 99241, SGV 99046, SGV 99048, SGV 99065, SGV 99024 and SGV 99032) and one control variety (S1R) were planted in four row-plots comprising of 20 seeds per row at spacing of $45 \mathrm{~cm} \times 15 \mathrm{~cm}$. Similarly the Spanish lines (ICGV SM 01502, ICGV SM 01504, ICGV SM 01510, ICGV SM 01514, ICGV SM 01515, ICGV SM 02501, ICGV SM 03590 ICGV SM 99555, and ICGV SM 99568) and one released improved variety (S4T) were planted in four row-plots, with 20 seeds per row at spacing of $45 \mathrm{~cm} \times 15 \mathrm{~cm}$. All experiments were carried out under natural conditions, and kept weed free by regular hand hoeing.

Geographic field location data that included altitude (Masl), latitude $\left(0^{\circ}\right)$ and longitude $\left(0^{\circ}\right)$ coordinates were collected using a Global Positioning System (GPS) device. General physical-chemical analyses of soil samples collected from the experimental fields at the $10-20 \mathrm{~cm}$ depth using an auger were carried out in the soil laboratory at the National Agricultural Research Laboratories (NaRL) at Kawanda in Kampala Uganda. Plant agronomic data were collected on the following parameters: days to germination; germinated seedlings at 2 - 4 weeks after planting; days to $50 \%$ flowering; days to plant maturity (DAP); yield (kg) per plot; dry grain yield (kg/ha); leaf spot disease incidence (1 - 9) and groundnut rosette mosaic virus incidence (number of plants with disease symptoms per plot). Natural leaf spot infection was assessed using the modified $1-9$ point scale at R6 (full seed-filling) and R8 (plant mature ready for harvest) stages as described by Subrahmanyam, et al., (1995) [19]: $1=0 \%$ disease severity (No disease); $2=1 \%-5 \%$ (lesions largely on lower leaves, defoliation); $3=6 \%-10 \%$ (lesions largely on lower leaves; very few lesions on middle leaves, defoliation of some leaflets evident on lower leaves); $4=11 \%-20 \%$ (lesions on lower and middle leaves; but severe on lower leaves; defoliation of some leaflets evident on lower leaves); $5=21 \%$ - 30\% (lesions on all lower and middle leaves; over $50 \%$ defoliation of lower leaves); $6=31 \%-40 \%$ (lesions severe on lower and middle leaves; lesions on top of leaves but less severe; extensive defoliation of lower leaves; defoliation of some leaflets evident on middle leaves); $7=41 \%-60 \%$ (lesions on all leaves but less severe on top leaves; defoliation of all lower and some middle leaves); $8=61 \%-80 \%$ (defoliation of all lower and middle leaves; lesions severe on top leaves and some defoliation of top leaves evident); $9=81 \%-100 \%$ (defoliation of almost all leaves leaving bare stems; some leaflets may be present, but with severe leaf spots). The groundnut levels of resistant to leaf spots based on the final disease incidence assessments on plants were categorized as: "Resistant" when the plant reaction to disease scored "1"; "Moderately-resistant" (score 2 - 3); "Moderately-susceptible" (score 4 - 5), "Susceptible" (score 6 - 7) and "highly susceptible" (score 8 - 9) [30]. The rosette mosaic virus disease was assessed as the percentage of the infected plants with symptoms per plot, and the percent rating was as follows: $<10 \%$ (highly resistant); $11 \%-30 \%$ (resistant); $31 \%-50 \%$ (moderately resistant) and $>50 \%$ (susceptible) [31]. 
All agronomic data collected were checked and entered into MS-excel spreadsheet, and analyzed using the Genstat Discovery Edition software VSN International Ltd., UK (Rothamsted Experimental Station). The data were analysed via one-way analysis of variance (ANOVA), and the significant means were separated using the least significant difference (LSD) test at $\mathrm{p} \leq 0.05$. The pearson correlation coefficients $(r)$ were calculated to determine the strength of relationships between the dependent and the independent variables using the following formula:

$$
r=\frac{n\left(\sum x y\right)-\left(\sum x\right)\left(\sum y\right)}{\sqrt{\left[n \sum x^{2}-\left(\sum x\right)^{2}\right]\left[n \sum y^{2}-\left(\sum y\right)^{2}\right]}}
$$

where $n$ was the total sample number, the $x$ values (independent variable: disease incidences) and the $y$ values (dependent variable: yield). The correlation coefficient value ranged between -1 and 1 , where -1 indicated a strong negative relationship, 1 indicated a strong positive relation and zero indicated no relationship [32].

\section{Results}

\subsection{Field Soil Chemical and Textural Characteristics}

All experimental fields had predominantly sandy soils (61\% - 66\% sand content), while the silt $(8 \%-10 \%)$ and clay $(24 \%-29 \%)$ contents were low (Table 1$)$. The low levels of silt and clay contents indicated that these soils had high water infiltration, low water and nutrient holding capacity, low organic matter, and were prone to wind erosion and rapid temperature variation. Apart from the exchangeable potassium $(\mathrm{K})$ content that was inadequate, the total exchangeable phosphorous $(\mathrm{P})$ and nitrogen $(\mathrm{N})$, which are responsible for vegetative growth, reproduction and podding were lower than the critical levels in all the three experimental fields. The soil $\mathrm{pH}$ tended to acidity, a level that was lower than the ideal level (5.3 - 6.8), and a condition reported to lead to poor: nodulation, root development and yield. The contents of Calcium (Ca) and Magnesium (Mg), which are very important in groundnut growth, pod filling and yield, were above the critical levels, and adequate for proper plant growth and high yields.

Table 1. Physical-chemical characteristics of soils from experimental fields in the South Western Agro-Ecological Zone of Uganda during 2014B, 2015A and 2015B.

\begin{tabular}{|c|c|c|c|c|c|c|c|c|c|c|c|}
\hline Season & $\mathrm{pH}$ & $\mathrm{OM}$ & $\mathbf{N}$ & $\mathbf{P}$ & $\mathrm{Ca}$ & $\mathrm{Mg}$ & K & Sand & Clay & Silt & Texture class \\
\hline & \multicolumn{4}{|c|}{$\%$} & \multicolumn{2}{|c|}{$\mathrm{ppm}$} & \multicolumn{5}{|c|}{$\%$} \\
\hline 2014B & 5.20 & 4.10 & 0.22 & 13.78 & 510.12 & 225.3 & 1142.9 & 61.1 & 28.9 & 10.0 & Sandy clay loam \\
\hline $2015 \mathrm{~A}$ & 5.00 & 3.40 & 0.18 & 9.88 & 393.54 & 163.2 & 306.2 & 65.8 & 24.2 & 10.0 & Sandy clay loam \\
\hline 2012B & 4.90 & 2.40 & 0.11 & 8.47 & 608.90 & 260.3 & 233.5 & 65.1 & 26.9 & 8.0 & Sandy clay loam \\
\hline Critical levels & 5.2 & 3.0 & 0.20 & $<90$ & 350.0 & 100.0 & 150.0 & & & & \\
\hline Sufficient levels & $5.2-7.0$ & 6.0 & 0.30 & $90-230$ & 2000.0 & 600.0 & 500.0 & & & & \\
\hline
\end{tabular}




\subsection{Agronomic Performance of Improved Groundnuts in the SWAEZ}

\subsubsection{Serenut Varieties}

Although groundnut require $500-700 \mathrm{~mm}$ of rainfall per season, and the optimum temperature range of $22^{\circ} \mathrm{C}-28^{\circ} \mathrm{C}$, the weather conditions in the SWAEZ were unfavourable to the several varieties especially the drought-sensitive and late maturing ones. The Serenut varieties (Table 2), which are popular in the Eastern and Northern Uganda, were tested on-station in the SWAEZ. The periods for Serenut plant germination during 2014B, 2015A and 2015B were 14 $18,17-26$ and $12-17$ days after planting (DAP), respectively. Although plant

Table 2. Description of Serenut varieties tested in the current study in the South Western Agro-Ecological Zone of Uganda during 2014B, 2015A and 2015B.

\begin{tabular}{|c|c|c|c|c|c|c|}
\hline $\begin{array}{l}\text { Variety } \\
\text { name }\end{array}$ & $\begin{array}{l}\text { Year of } \\
\text { release }\end{array}$ & $\begin{array}{c}\text { Owners } \\
\text { and seed } \\
\text { source in } \\
\text { Uganda }\end{array}$ & $\begin{array}{l}\text { Characteristics } \\
\text { (grain colour) }\end{array}$ & $\begin{array}{l}\text { Duration to } \\
\text { maturity } \\
\text { (days) }\end{array}$ & $\begin{array}{l}\text { Grain yield } \\
(\mathrm{Kg} / \mathrm{ha})\end{array}$ & Special attributes \\
\hline $\begin{array}{l}\text { Serenut } 1 \\
\text { Red (S1R) }\end{array}$ & 1995 & NARO & Red & $100-110$ & $2700-3700$ & $\begin{array}{l}\text { Virginia, red seeded } \\
\text { Resistant to leaf spot } \\
\text { Tolerant to drought } \\
\text { Good for confectionary }\end{array}$ \\
\hline $\begin{array}{l}\text { Serenut } 2 \\
\text { (S2) }\end{array}$ & 1998 & NARO & Tan & $100-110$ & $2700-3500$ & $\begin{array}{l}\text { Virgina, striped } \\
\text { Resistant to groundnut } \\
\text { rosette mosaic virus } \\
\text { Tolerant to drought } \\
\text { Good for confectionary }\end{array}$ \\
\hline $\begin{array}{l}\text { Serenut } 3 \\
\text { Red (S3R) }\end{array}$ & 2002 & NARO & Red & $90-100$ & $2500-2900$ & $\begin{array}{l}\text { Spanish, red seeded } \\
\text { Resistant to leaf spot } \\
\text { Resistant to groundnut } \\
\text { rosette mosaic virus } \\
\text { High oil content, good } \\
\text { for butter }\end{array}$ \\
\hline $\begin{array}{c}\text { Serenut } 4 \\
\text { Tan }(\mathrm{S} 4 \mathrm{~T})\end{array}$ & 2002 & NARO & Pale pink & $90-100$ & $2500-2900$ & $\begin{array}{c}\text { Spanish, tan seeded } \\
\text { Resistant to aphid (Aphis } \\
\text { craccivora) vector } \\
\text { of rosette mosaic virus } \\
\text { High shelling } \\
\text { Good for confectionary }\end{array}$ \\
\hline $\begin{array}{l}\text { Serenut } 5 \\
\text { Red (S5R) }\end{array}$ & 2010 & NARO & Red & $100-110$ & $2500-3000$ & $\begin{array}{l}\text { Virginia, red seeded } \\
\text { Resistant to groundnut } \\
\text { rosette mosaic virus } \\
\text { Tolerant to drought } \\
\text { Short dormancy } \\
\text { Good for confectionary }\end{array}$ \\
\hline $\begin{array}{l}\text { Serenut } 6 \\
\text { Tan (S6T) }\end{array}$ & 2010 & NARO & Tan & $90-100$ & $2500-3000$ & $\begin{array}{l}\text { Spanish, tan seeded } \\
\text { Resistant to groundnut } \\
\text { rosette mosaic virus } \\
\text { Good for confectionary }\end{array}$ \\
\hline
\end{tabular}

Sources: Okello, D. K., Monyo, E., Deom C.M., Ininda, J., \& Oloka, H. K. 2013. Groundnuts production guide for Uganda: Recommended practices for farmers. National Agricultural Research Organisation, Entebbe. 
germination dates significantly varied among the varieties within each season, most varieties germinated within 12.4 - 18.0 DAP (Table 3). However, significantly high changes in days to germination of Serenut $1 \mathrm{R}$ during $2015 \mathrm{~A}$ and 2015B; Serenut 2 and Serenut 3R during 2015A were observed. In the 2015A season, Serenut $4 \mathrm{~T}$, Serenut $6 \mathrm{~T}$ and the local varieties germinated early while the rest took more days to germinate. Varieties that showed earliness during 2015A also germinated early in 2015B, but the days to germination increased by $2-3$ among the early and 8 - 9 among the late varieties during 2015B (Table 3).

The overall plant germination rates significantly varied within each season $\left(2014 \mathrm{~B} \mathrm{R}^{2}=0.0294,20115 \mathrm{~A} \mathrm{R}^{2}=0.0094\right.$ and 2015B R $\left.\mathrm{R}^{2}=0.009\right)$, and among the three seasons, where $2014 \mathrm{~B}, 2015 \mathrm{~A}$ and $2015 \mathrm{~B}$ had germination rates of 55.0 100, 44.7 - 88.6 and 43.9 - 76.9 (Table 3), respectively. Apart from Serenut 3R and Serenut $1 \mathrm{R}$, the rest of the Serenuts' germination rates were significantly high with Serenut 5R having 100\% germination during 2014B. The germination rates of the local variety were $93.8 \%, 88.6 \%$ and $66.7 \%$ during $2014 \mathrm{~B}, 2015 \mathrm{~A}$ and 2015B, respectively. Although, the percentage germination of most varieties slightly reduced in $2015 \mathrm{~B}$ compared to the $2015 \mathrm{~A}$, the varieties that expressed consistently high germinability during 2015A maintained it during 2015B. For example, Serenut $4 \mathrm{~T}$, Serenut $5 \mathrm{R}$ and Serenut $6 \mathrm{~T}$ showed very high germinability like the well adapted local variety. Serenut $1 \mathrm{R}$, Serenut 2 and Serenut $3 \mathrm{R}$ had low germination rates during the three seasons.

During 2014B, all varieties including the local check started flowering during the same period of one week (40 - 46 DAP) with the earliest starting at $40 \mathrm{DAP}$ after planting, and reached 50\% flowering stage within one week (at $46 \mathrm{DAP}$ ). In 2015B, the early flowering varieties started at $35 \mathrm{DAP}$ and reached 50\% flowering

Table 3. Germination and flowering periods of six improved groundnut varieties in the South Western Agro-Ecological Zone of Uganda during 2014B, 2015A and 2015B.

\begin{tabular}{|c|c|c|c|c|c|c|c|c|c|c|c|c|}
\hline \multicolumn{5}{|c|}{ 2014B } & \multicolumn{4}{|c|}{$2015 A$} & \multicolumn{4}{|c|}{ 2015B } \\
\hline Variety & ○ 总 & 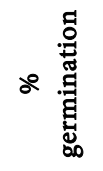 & 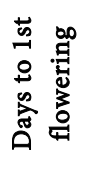 & 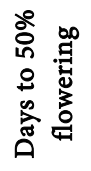 & 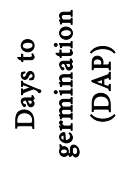 & 。 . & 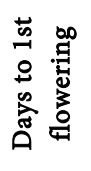 & 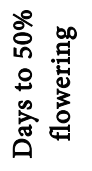 & ○ & 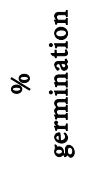 & 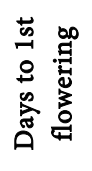 & 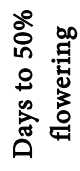 \\
\hline Serenut 5R & 18.0 & 100.0 & 42.0 & 46.0 & 17.0 & 74.2 & 35.3 & 39.0 & 12.4 & 76.9 & 38.3 & 42.0 \\
\hline Serenut 2 & 18.0 & 68.3 & 46.0 & 57.0 & 25.3 & 46.9 & 40.3 & 50.0 & 17.7 & 43.9 & 33.7 & 43.7 \\
\hline Serenut $4 \mathrm{~T}$ & 15.0 & 62.5 & 41.0 & 57.0 & 17.0 & 88.6 & 35.3 & 39.0 & 13.0 & 71.4 & 37.7 & 52.0 \\
\hline Serenut 3R & 18.0 & 45.0 & 40.0 & 46.0 & 25.7 & 56.7 & 35.7 & 39.0 & 16.7 & 44.4 & 35.0 & 39.7 \\
\hline Serenut $6 \mathrm{~T}$ & 14.0 & 82.1 & 41.0 & 46.0 & 17.0 & 71.4 & 35.3 & 39.0 & 13.0 & 70.0 & 38.0 & 53.0 \\
\hline Serenut $1 \mathrm{R}$ & 18.0 & 55.0 & 44.0 & 57.0 & 25.7 & 44.7 & 45.0 & 53.0 & 22.7 & 68.1 & 34.3 & 43.3 \\
\hline Local & 14.0 & 93.8 & 40.0 & 46.0 & 17.0 & 88.6 & 34.7 & 43.3 & 12.7 & 66.7 & 37.0 & 52.2 \\
\hline $\operatorname{LSD}_{(\mathrm{P} \leq 0.05)}$ & 0.3 & 5.7 & 1.4 & NS & 6.8 & 19.1 & 2.4 & 6.0 & 5.7 & 15.6 & NS & NS \\
\hline CV \% & 1.8 & 8.1 & 3.4 & 28.0 & 18.9 & 16.2 & 3.6 & 8.0 & 21.2 & 14.1 & 32.7 & 41.9 \\
\hline
\end{tabular}


stage at 39 DAP (4 - 8 days). Serenut 3R, the Local variety, Serenut $6 \mathrm{~T}$ and Serenut $4 \mathrm{~T}$ showed earliness in germination and flowering while Serenut 1 and Serenut 2 germinated and flowered late. Serenut $5 \mathrm{R}$ expressed very high germinability and was moderately early-flowering (Table 3 ).

Based on the final disease assessment, all varieties were infected by leaf spot causing pathogens during 2015A and 2015B, but the disease incidences were not correlated to period of disease appearance. During 2015A, the leaf spot disease appeared at 8 weeks after planting (about two months after planting) but the initial disease incidence scores were generally low on all varieties. At R8 plant growth stage, higher leaf spot incidences occurred in the 2015B than in the 2015A season (Table 4). During 2015A, the local variety, Serenut 4T and Serenut $6 \mathrm{~T}$ showed moderately-susceptible responses to leaf spots. Serenut 2 and Serenut $1 \mathrm{R}$ were resistant while Serenut $5 \mathrm{R}$ and Serenut $3 \mathrm{R}$ displayed moderately-resistant responses (Table 4). During 2015B, Serenut $4 \mathrm{~T}$ and Serenut $6 \mathrm{~T}$ were susceptible while the local variety and Serenut $5 \mathrm{R}$ (Figure 2) were moderately-susceptible. Serenut 1R, Serenut 2 and Serenut 3R were moderately-resistant. Therefore, Serenut 1R, 2 and 3R, which displayed higher levels of leaf spot disease resistance were identified as suitable for growing in the SWAEZ where leaf spots have become endemic like elsewhere worldwide [33].

The incidences of rosette mosaic virus disease on the Serenut varieties were generally low during 2014B, 2015A and 2015B (Table 4). Apart from Serenut 5R that was not infected during the three seasons, the rest of the varieties had varying low incidences of infection across season, but among the varieties, Serenut $3 \mathrm{R}$ and $6 \mathrm{~T}$ expressed high levels of rosette mosaic tolerance. The local variety

Table 4. Leaf spot and rosette mosaic disease incidences on improved groundnut varieties in the South Western Agro-Ecological Zone of Uganda during 2014B, 2015A and 2015B.

\begin{tabular}{|c|c|c|c|c|c|c|}
\hline \multirow[t]{2}{*}{ Variety } & \multicolumn{3}{|c|}{ Leaf spot incidence at harvest $(1-9)$} & \multicolumn{3}{|c|}{$\%$ Rosette Mosaic incidence at harvest } \\
\hline & $\begin{array}{l}\text { Days to first leaf } \\
\text { spot appearance }\end{array}$ & $2015 \mathrm{~A}$ & 2015B & 2014B & $2015 \mathrm{~A}$ & 2015B \\
\hline Serenut $5 \mathrm{R}$ & 57.0 & $2.3(\mathrm{MR})$ & 4.7 (MS) & 0.0 (HR) & $0.0(\mathrm{HR})$ & $0.0(\mathrm{HR})$ \\
\hline Serenut 2 & 62.0 & $1.3(\mathrm{R})$ & $3.2(\mathrm{MR})$ & 0.0 (HR) & $0.0(\mathrm{HR})$ & 1.7 (HR) \\
\hline Serenut $4 \mathrm{~T}$ & 59.5 & $4.2(\mathrm{MS})$ & $6.5(S)$ & $5.6(\mathrm{HR})$ & $5.6(\mathrm{HR})$ & $1.5(\mathrm{HR})$ \\
\hline Serenut 3R & 58.5 & $2.2(\mathrm{MR})$ & 2.0 (MR) & $0.0(\mathrm{HR})$ & $0.6(\mathrm{HR})$ & 0.9 (HR) \\
\hline Serenut $6 \mathrm{~T}$ & 61.0 & $4.0(\mathrm{MS})$ & $6.2(S)$ & 3.3 (HR) & $3.3 \mathrm{HR})$ & $4.1(\mathrm{HR})$ \\
\hline Serenut $1 \mathrm{R}$ & 60.0 & $1.3(\mathrm{R})$ & $1.7((\mathrm{MR})$ & $8.6(\mathrm{HR})$ & 9.4 (HR) & $11.6(\mathrm{R})$ \\
\hline Local & 58.5 & $5.3(\mathrm{MS})$ & $5.2(\mathrm{MS})$ & 6.7 (HR) & 7.5 (HR) & $15.1(\mathrm{R})$ \\
\hline $\operatorname{LSD}_{(\mathrm{P} \leq 0.05)}$ & 2.0 & 0.9 & 1.5 & 5.5 & 5.9 & NS \\
\hline $\mathrm{CV} \%$ & 3.3 & 16.9 & 20.5 & 91.5 & 48.8 & 17.0 \\
\hline
\end{tabular}

Classification of leaf spot incidence and resistance scores: Resistant $(R)=1$; moderately resistant $(M R)=2$ 3; moderately susceptible (MS) $=4-5$; susceptible $(\mathrm{S})=6-7$ and highly susceptible $(\mathrm{HS})=8-9$. Rosette mosaic virus disease resistance rating: <10\% (highly resistant, HR); $11 \%-30 \%$ (resistant, R); 31\% - 50\% (moderately resistant, MR) and $>50 \%$ (susceptible, $\mathrm{S}$ ). 

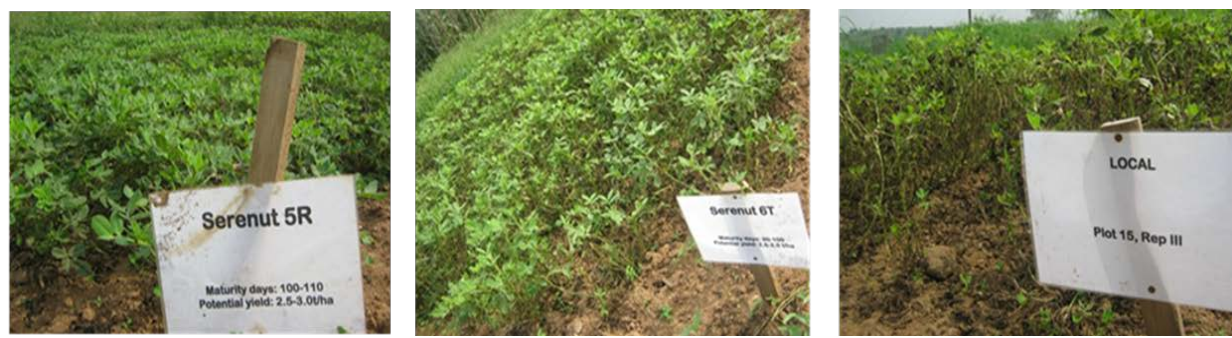

Figure 2. Severity of leaf spot diseases on resistant (left: Serenut 5R), moderately-resistant (centre: Serenut 6T) and susceptible (right: Local variety) in the South Western Agro-Ecological Zone, Uganda.

and Serenut $1 \mathrm{R}$ had slightly higher average disease incidences, while the least infected varieties were Serenut 2 and Serenut 3R. Apart from Serenut 1; Serenut 2, $3 \mathrm{R}, 4 \mathrm{~T}, 5 \mathrm{R}$ and $6 \mathrm{~T}$ were highly tolerant to rosette mosaic virus disease in the SWAEZ, moreover, Serenut 2 and Serenut $3 \mathrm{R}$ have been previous identified as resistant [34].

All varieties showed a non-significantly different level of plant survival (85.7\% - 100.0\%) at harvest, which indicated high stress tolerance abilities in the Serenut genotypes. However, there was no correlation between the percent plant survival and yield. The yield performances of the Serenut varieties were generally low (Table 5) compared to the expected $2500-3000 \mathrm{Kg} / \mathrm{ha}$ [24]. On average, no significant differences between yields from the local and the improved varieties were observed during the three seasons. Apart from Serenut 5R that had significantly higher average yields $(1528 \mathrm{Kg})$ than the local varieties, all yields from other improved varieties were not significantly different from the local varieties' yields during 2014B. Interestingly, Serenut $1 \mathrm{R}$ and Serenut 3R had lower yields than the local variety in 2014B. During 2015B, Serenut 5R, Serenut 4T and Serenut $6 \mathrm{~T}$ had significantly higher yields than Serenut $1 \mathrm{R}$, Serenut 2 and Serenut 3R (Table 5). Overall, Serenut $1 \mathrm{R}$ and Serenut $3 \mathrm{R}$ had the lowest average yields of $512 \mathrm{Kg} / \mathrm{ha}$ and $619 \mathrm{Kg} / \mathrm{ha}$, respectively, during the entire three seasons. Serenut 5R was the earliest maturing, virus tolerant and high yielding variety. Based on the three seasons' findings, Serenut 5R, Serenut $4 \mathrm{~T}$ and Serenut $6 \mathrm{~T}$ were identified as the most yielding and highly adaptable to the SWAEZ conditions.

\subsubsection{AGRA Red Lines}

Under normal situations, groundnuts are planted towards the end of the dry period (late February and late August) or just after the beginning of the first and second seasons' rainfall (early March and early September) in the SWAEZ. However, this was not the case for the 2014B and 2015A cropping seasons because of the late and insufficient rainfall received, which led to late sowing by about one month. Although groundnut seed is known to germinate within $5-10$ days after sowing, this study found out that the AGRA red lines took 14 - 18, 19 29 and 13 - 24 days after planting (DAP) to germinate during 2014B, 2015A and 2015B (Table 6), respectively. Apart from SGV 99065 that consistently germinated late during the three seasons, there were no significant differences in days 
Table 5. Plant survival and yield performance of six improved groundnut varieties in the South Western Agro-Ecological Zone of Uganda during 2014B, 2015A and 2015B.

\begin{tabular}{cccccc}
\hline Variety & \% plant survival & \multicolumn{2}{c}{ Yield Kg/ha } & \% plant survival & Yield Kg/ha \\
\hline & 2014B & 2014B & 2015A & 2015B & 2015B \\
\hline Serenut 5R & 94.1 & 1528.1 & 731.0 & 74.2 & 1047.0 \\
Serenut 2 & 100.0 & 833.2 & 484.0 & 43.6 & 802.0 \\
Serenut 4T & 86.7 & 833.2 & 741.0 & 71.9 & 1350.0 \\
Serenut 3R & 92.5 & 667.2 & 667.0 & 51.1 & 449.0 \\
Serenut 6T & 93.8 & 1028.0 & 637.0 & 67.5 & 891.0 \\
Serenut 1R & 85.7 & 583.0 & 346.0 & 70.8 & 607.0 \\
Local & 96.9 & 778.0 & 395.0 & 55.0 & 1019.0 \\
LSD (Ps0.05) & NS & 435.2 & 251.0 & 14.8 & 532.0 \\
CV \% & 5.5 & 17.2 & 25.0 & 13.7 & 35.0 \\
\hline
\end{tabular}

Table 6. Germination and flowering periods of advanced AGRA red lines in the South Western Agro-Ecological Zone of Uganda during 2014B, 2015A and 2015B.

\begin{tabular}{|c|c|c|c|c|c|c|c|c|c|c|c|c|c|c|}
\hline \multirow[t]{2}{*}{ Variety } & \multicolumn{5}{|c|}{ 2014B } & \multicolumn{5}{|c|}{$2015 A$} & \multicolumn{4}{|c|}{ 2015B } \\
\hline & 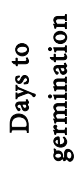 & 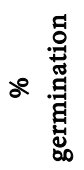 & 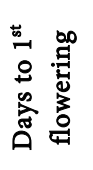 & 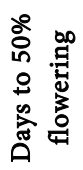 & $\sum_{\substack{3 \\
0}}^{3}$ & 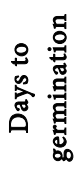 & 。 & 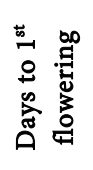 & 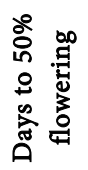 & 疍 & 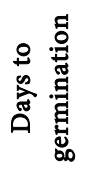 & 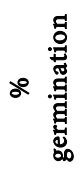 & 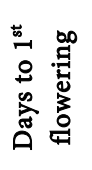 & 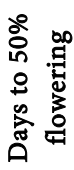 \\
\hline SGV 99046 & 15.5 & 82.5 & 43.0 & 58.0 & 100.0 & 23.8 & 57.7 & 39.0 & 45.5 & 76.3 & 19.3 & 61.7 & 22.0 & 35.0 \\
\hline SGV 99019 & 16.5 & 71.9 & 41.0 & 55.5 & 98.0 & 19.5 & 56.8 & 39.3 & 46.8 & 85.9 & 15.0 & 65.0 & 27.8 & 35.0 \\
\hline SGV 99241 & 14.5 & 88.1 & 42.0 & 60.0 & 97.0 & 24.8 & 50.0 & 41.8 & 48.0 & 85.1 & 15.8 & 85.6 & 30.0 & 36.5 \\
\hline SGV 99032 & 15.5 & 78.8 & 40.5 & 56.8 & 100.0 & 20.8 & 53.0 & 41.3 & 47.3 & 87.3 & 15.3 & 64.2 & 28.0 & 36.0 \\
\hline SGV 99064 & 16.3 & 90.0 & 42.5 & 57.3 & 100.0 & 22.5 & 66.1 & 40.5 & 46.0 & 81.3 & 17.0 & 80.6 & 25.0 & 36.3 \\
\hline SGV 99024 & 15.3 & 99.1 & 43.8 & 56.0 & 100.0 & 20.8 & 69.0 & 45.0 & 51.3 & 77.1 & 15.0 & 82.3 & 32.8 & 38.5 \\
\hline SGV 99065 & 18.0 & 75.0 & 43.0 & 58.0 & 97.0 & 29.0 & 49.7 & 41.5 & 47.5 & 91.2 & 23.5 & 69.0 & 19.5 & 37.0 \\
\hline SGV 99043 & 16.0 & 80.0 & 42.0 & 55.0 & 99.0 & 26.3 & 50.6 & 42.8 & 50.0 & 82.7 & 18.5 & 68.3 & 29.8 & 37.5 \\
\hline $\operatorname{LSD}_{(\mathrm{P} \leq 0.05)}$ & 2.3 & 11.6 & NS & 2.5 & NS & NS & NS & 3.8 & 4.2 & NS & NS & NS & 7.0 & NS \\
\hline $\mathrm{CV} \%$ & 9.9 & 9.5 & 5.4 & 3.1 & 2.8 & 20.1 & 25.1 & 6.5 & 6.1 & 13.6 & 25.8 & 23.5 & 18.1 & 7.2 \\
\hline
\end{tabular}

to germination among the other lines and the control. Unlike Serenut 1R, which germinated earlier, most AGRA red lines took longer to germinate especially during the 2015A season that experienced a long dry spell and received insufficient rain (Figure 1).

The rate of germination varied across the three seasons mainly due to variations in the amount and pattern of rainfall. All lines planted on $30^{\text {th }}$ September 2014 had significantly high germination rates during the $2014 \mathrm{~B}$ season. The nine 
AGRA red lines showed moderate - high rates of germination (Table 6) across the three seasons under the South Western semi-arid conditions. During 2014B, percentage plant germination ranged from $72 \%$ to $99 \%$, with SGV 99064 and SGV 99024 having signficantly high rates of germination compared to the control S1R (92\%). The 2015A crop, which concided with a very long dry spell took a long period to germinate, and had a lower percentage germination range of $50 \%$ - 69\% compared to the $2014 \mathrm{~B}$ crop. The 2015B season, which received higher rainfall for a longer period (July-December), had intermediate rate of germination $(57 \%-86 \%)$ that was not significantly different at $\mathrm{p} \leq 0.05$. Lines SGV 99064 and SGV 99024 consistently had the highest percentage germination across the three seasons.

Like germination, the days to $50 \%$ flowering also varied across seasons, and the variations among AGRA lines within the same season were low. The 2015B crop flowered within 34 - 39 days, while the 2014B and 2015A took 55 - 60 and 45 - 51 days, respectively (Table 6). The inadequate rainfall received by groundnut crops negatively affected the agronomic performance of the improved lines at flowering, podding and maturing stages.

Although the leaf spot diseases appeared around 44 - 48 days after planting, their incidences on the AGRA red lines during 2014B, 2015A and 2015B were generally low, but significantly different among all lines during 2015B (Table 7).

Table 7. Groundnut leaf spot disease and Rosette Mosaic Virus (GRD) incidences on advanced AGRA red lines in the South Western Agro-Ecological Zone of Uganda during 2014B, 2015A and 2015B.

\begin{tabular}{|c|c|c|c|c|c|c|}
\hline \multirow[t]{2}{*}{ Variety } & \multicolumn{2}{|c|}{$2015 A$} & \multicolumn{2}{|c|}{ 2015B } & \multicolumn{2}{|c|}{$2015 B$} \\
\hline & $\begin{array}{c}\text { Leaf spot } \\
\text { incidence } \\
(1-9 \text { scale })\end{array}$ & $\begin{array}{l}\text { Level of } \\
\text { resistance }\end{array}$ & $\begin{array}{c}\text { Leaf spot } \\
\text { incidence } \\
(1-9 \text { scale })\end{array}$ & $\begin{array}{c}\text { Level of } \\
\text { resistance }\end{array}$ & $\%$ GRD & $\begin{array}{c}\text { Level of } \\
\text { Resistance }\end{array}$ \\
\hline SGV 99048 & 1.8 & MR & 1.3 & $\mathrm{R}$ & 0.0 & $\mathrm{HR}$ \\
\hline SGV 99046 & 1.8 & MR & 1.3 & $\mathrm{R}$ & 0.2 & HR \\
\hline SGV 99019 & 1.8 & MR & 1.6 & MR & 0.6 & $\mathrm{HR}$ \\
\hline SGV 99241 & 1.8 & MR & 1.8 & MR & 0.4 & $\mathrm{HR}$ \\
\hline SGV 99032 & 1.8 & MR & 1.4 & $\mathrm{R}$ & 0.4 & HR \\
\hline S1R & 1.8 & MR & 1.9 & MR & 2.9 & $\mathrm{HR}$ \\
\hline SGV 99064 & 1.9 & MR & 1.5 & MR & 0.4 & $\mathrm{HR}$ \\
\hline SGV 99024 & 1.6 & MR & 1.5 & MR & 0.4 & HR \\
\hline SGV 99065 & 1.8 & MR & 1.1 & $\mathrm{R}$ & 0.4 & $\mathrm{HR}$ \\
\hline SGV 99043 & 1.6 & MR & 1.8 & MR & 0.0 & $\mathrm{HR}$ \\
\hline $\operatorname{LSD}_{(\mathrm{P} \leq 0.05)}$ & NS & & 0.5 & & 1.7 & \\
\hline $\mathrm{CV} \%$ & 17.6 & & 25.1 & & 19.8 & \\
\hline
\end{tabular}

Level of varietal resistance to leaf spot diseases: R: "Resistant" when the plant reaction to disease scored "1"; MR: "Moderately-resistant" (score 2 - 3); MS: "Moderately-susceptible" (score 4 - 5), S: "Susceptible" (score 6 7) and HS: "highly susceptible" (score 8 - 9). $<10 \%$ (highly resistant: HR); 11\% - 30\% (resistant: R); 31\% $50 \%$ (moderately resistant: MR) and $>50 \%$ (susceptible: $\mathrm{S}$ ). 
Based on the modified 9-point scale, this study showed that the AGRA red lines responded with varying moderate $(\mathrm{MR})$ to high $(\mathrm{R})$ levels of resistance to leaf spots (Figure 3) under the different seasons and weather conditions. Because of the very low level of resistance in the AGRA red lines, there was probably no negative impact of the disease on the yield performance of these genotypes. Grountnut rosette mosaic virus (GRD) (Figure 4) infected all varieties, but its incidences were significantly low $(0.0 \%-2.9 \%)$ during $2015 \mathrm{~B}$ (Table 7$)$. Therefore, the study determined that AGRA red lines were highly resistant (HR) to the rosette mosaic virus.

The yielding potential of the AGRA red groundnut was assessed basing on fresh haulm weight, number of pods harvested, fresh pod-weight, 100 seed-weight, dry pod-weight and marketable dry grain-weight. These lines show non significant levels of plant survival at maturity $(97 \%-100 \%, 77 \%-92 \%$ and $89 \%$ $100 \%$ ), respectively, during 2014B, 2015A and 2015B. Although the amounts of varietal fresh haulms harvested in 2015A and 2015B were not significantly different (Table 8), the 2014B plant haulm yields were significantly different at $\mathrm{p} \leq$ 0.05 . Serenut 1R (control) had the highest haulm yield, which was not significantly different from the yields of six AGRA red lines (SGV 990048, SGV 99046, SGV 99019, SGV 99241, SGV 99032 and SGV 99024). The average ranges of

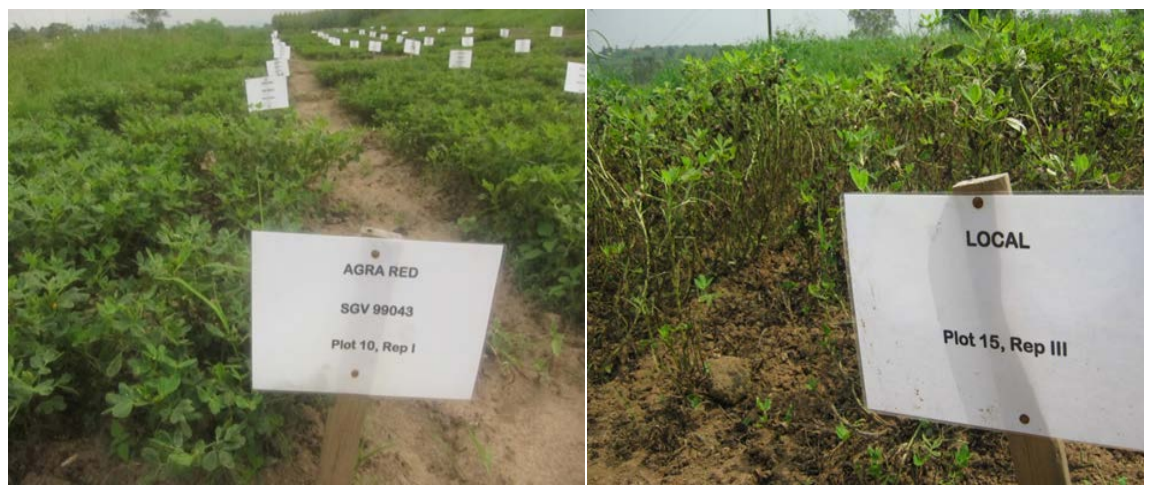

Figure 3. Leaf spot infection on AGRA red lines (left) and a local variety (right) in the South Western Agro-Ecological Zone of Uganda.
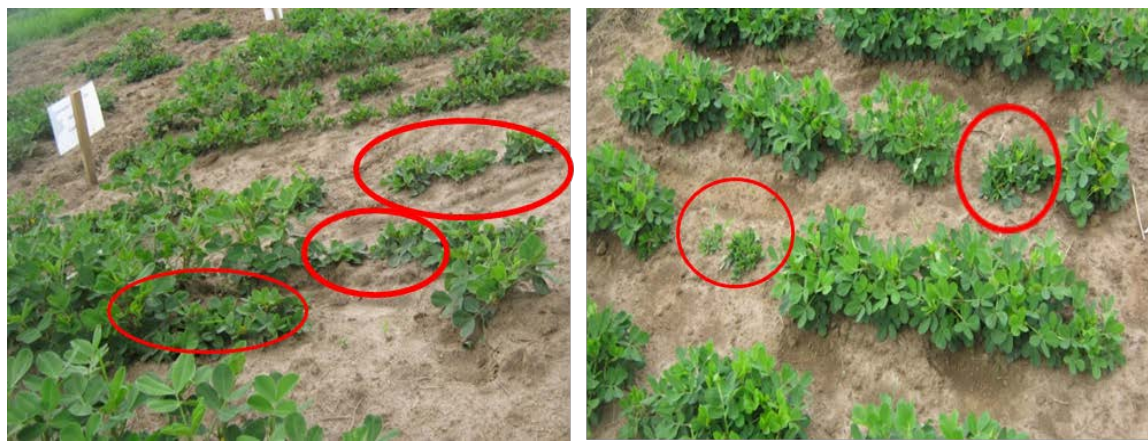

Figure 4. Rosette virus disease (GRD) infected AGRA red (left. SGV 99019) and Spanish (right: ICGV SM 03590) groundnut plants in the South Western Agro-Ecological Zone of Uganda. 
Table 8. Agronomic performance of advanced AGRA red lines in the South Western Agro-Ecological Zone of Uganda during 2014B, 2015A and 2015B.

\begin{tabular}{|c|c|c|c|c|c|c|c|c|c|c|}
\hline \multirow[b]{2}{*}{ Variety } & \multicolumn{3}{|c|}{ 2014B } & \multicolumn{4}{|c|}{$2015 \mathrm{~A}$} & \multicolumn{3}{|c|}{$2015 B$} \\
\hline & $\begin{array}{c}\text { Haulms } \\
\text { yield } \\
(\mathrm{Kg} / \mathrm{ha})\end{array}$ & $\begin{array}{c}\text { Fresh pod } \\
\text { yields } \\
(\mathrm{Kg} / \mathrm{ha})\end{array}$ & $\begin{array}{l}\text { Weight of } \\
100 \text { seeds } \\
\text { (g) }\end{array}$ & $\begin{array}{c}\text { Haulms } \\
\text { yield } \\
(\mathrm{Kg} / \mathrm{ha})\end{array}$ & $\begin{array}{c}\text { Fresh pod } \\
\text { weight } \\
(\mathrm{Kg} / \mathrm{ha})\end{array}$ & $\begin{array}{c}\text { Actual dry } \\
\text { pod yield } \\
(\mathrm{Kg} / \mathrm{ha})\end{array}$ & $\begin{array}{l}\text { Weight of } \\
100 \text { seeds } \\
\text { (g) }\end{array}$ & $\begin{array}{c}\text { Haulms } \\
\text { yield } \\
(\mathrm{Kg} / \mathrm{ha})\end{array}$ & $\begin{array}{c}\text { Actual dry } \\
\text { pod Yield } \\
(\mathrm{Kg} / \mathrm{ha})\end{array}$ & $\begin{array}{c}\text { Weight of } \\
100 \text { seeds } \\
\text { (g) }\end{array}$ \\
\hline SGV 99048 & 17593.0 & 6327.0 & 52.2 & 4259.0 & 2630.0 & 1415.0 & 49.5 & 13148.0 & 1111.0 & 42.3 \\
\hline SGV 99046 & 16667.0 & 6605.0 & 52.9 & 3667.0 & 2593.0 & 1348.0 & 47.0 & 12963.0 & 815.0 & 50.5 \\
\hline SGV 99019 & 14815.0 & 6327.0 & 52.7 & 4296.0 & 3074.0 & 1826.0 & 49.5 & 14259.0 & 1000.0 & 43.3 \\
\hline SGV 99241 & 15741.0 & 7099.0 & 50.7 & 3593.0 & 3333.0 & 2478.0 & 48.0 & 17222.0 & 1593.0 & 39.0 \\
\hline SGV 99032 & 14506.0 & 5648.0 & 49.3 & 3926.0 & 3111.0 & 1989.0 & 45.0 & 11593.0 & 1111.0 & 40.5 \\
\hline S1R & 19136.0 & 6821.0 & 47.6 & 4630.0 & 2778.0 & 1659.0 & 46.0 & 13704.0 & 1407.0 & 44.5 \\
\hline SGV 99064 & 13272.0 & 5864.0 & 48.9 & 5074.0 & 3481.0 & 2148.0 & 44.0 & 15000.0 & 926.0 & 50.0 \\
\hline SGV 99024 & 16049.0 & 6049.0 & 44.9 & 5519.0 & 3519.0 & 2163.0 & 42.0 & 14815.0 & 1074.0 & 46.0 \\
\hline SGV 99065 & 12037.0 & 4753.0 & 52.4 & 3444.0 & 2407.0 & 1230.0 & 44.0 & 16481.0 & 778.0 & 46.5 \\
\hline SGV 99043 & 13580.0 & 4753.0 & 41.1 & 3148.0 & 2259.0 & 1130.0 & 40.5 & 15556.0 & 778.0 & 38.5 \\
\hline $\operatorname{LSD}_{(\mathrm{p} \leq 0.05)}$ & 6122.1 & 1581.3 & 4.6 & NS & NS & NS & 3.1 & NS & 383.7 & 4.8 \\
\hline CV \% & 27.6 & 18.2 & 6.5 & 43.4 & 44.0 & 57.4 & 15.6 & 21.6 & 25.1 & 7.6 \\
\hline
\end{tabular}

pods per plant during 2014B, 2015A and 2015B were 22.4-33.2, $18.8-31.0$ and 16.1 - 27.0, respectively. While there was clear indication that the advanced AGRA red lines were able to give higher haulm yields in the zone, their yielding potential was not significantly higher than that of the improved S1R variety. Based on the haulm yield, S1R yielded better than all the AGRA red lines, but when the dry grain weight was considered, SGV 99046, SGV 99241 and SGV 99064 had higher yields (Figure 5).

While the average fresh biomass yields of most lines were over $10 \mathrm{t} / \mathrm{ha}$ during $2014 \mathrm{~B}$, in the 2015A the same yield parameters were low (Less than $5 \mathrm{t} / \mathrm{ha}$ ) for most lines. The dry grain yields harvested during 2015A from each of nine lines were very low and not significantly different. The dry grain yield performances of all AGRA red lines during 2015A and 2015B (Figure 5) were lower than that of the control varieties in the SWAEZ. During 2015A, the dry grain yields ranged from $419 \mathrm{Kg} / \mathrm{ha}$ to $652 \mathrm{Kg} / \mathrm{ha}$, while during 2015B, the grain yield range was $365-647 \mathrm{Kg} / \mathrm{ha}$. This low performance of improved AGRA red lines was attributed to the unfavourable weather conditions that were dominated by prolonged dry periods. The consistently low yielding of the AGRA red lines during the three seasons was attributed to inadequate soil moisture due to low rainfall an indicator of the negative effects of climatic change on crop production in Uganda. Inconsistencies in the agronomic performance of the nine AGRA red lines showed that lines, which had higher yields during 2014B were not the same during 2015A (Figure 5). The high percentage (97\% - 100\%) plant survival range of the groundnut lines at maturity was not significantly different from that 


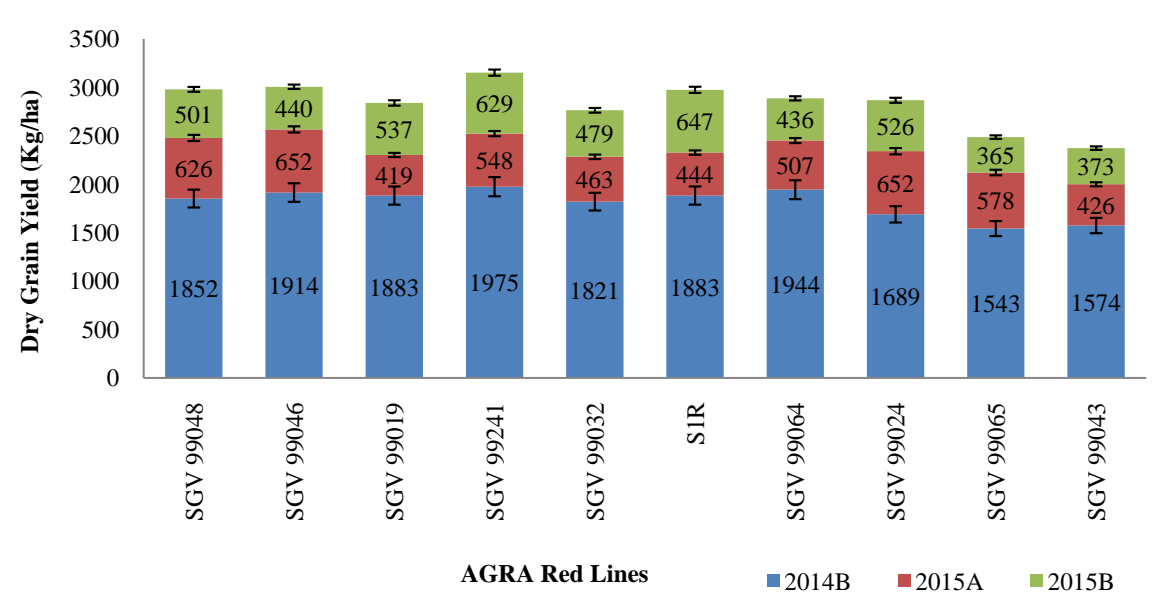

Figure 5. Yield performance of advanced AGRA red lines in the South Western Agro-Ecological Zone of Uganda during 2014B, 2015A and 2015B.

of SIR (95\%). The late maturing lines (SGV 99241 and SGV 99046), yielded better than the early maturing ones (SGV 99065 and SGV 99043). The promising SGV lines identified for further the research and adaptation were SGV 99241, SGV 99046, SGV 99064, SGV 99048, SGV 99019 and SGV 99032.

\subsubsection{Spanish Lines}

Spanish lines germinated early ( 2 weeks), and subsequently, most lines flowered around the same period as the control varieties (Table 9). While most lines flowered at 40 - 43 DAP, the late flowering lines (ICGV SM 01514, ICGV SM 02501 and ICGV SM 03590) took 45 - 48 days to flower during 2015A. Overall, the percentage germination of the Spanish lines ranged from $39.5 \%$ to $86.3 \%$ during $2015 \mathrm{~A}$, whereas it ranged from $43.1 \%$ to $86.2 \%$ during $2015 \mathrm{~B}$. While, the rates of germination varied among the lines and not across seasons, the germination rates of ICGV SM 99555, ICGV SM 01502, ICGV SM 99568, ICGV SM 01504 and ICGV SM 01515 were high, and not significantly different. On the other hand, ICGV SM 02501, ICGV SM 01510 and ICGV SM 03590 had the lowest germination rates during the two seasons (Table 9).

Leaf spot disease incidences on the Spanish lines varied across seasons, but the 2015A crop experienced higher infection than the 2015B crop (Table 10). Leaf spots appeared at around 47 - 59 days after planting, and six lines were severely infected before maturity, while ICGV SM 01514, ICGV SM 02501 (Figure 6) and ICGV SM 03590 reacted with high levels of resistance during 2015A. Although, the leaf spot infections were lower during 2015B, ICGV SM 02501, ICGV SM 01515, ICGV SM 01514 and ICGV SM 01502 showed moderate-resistance (MR) to resistance (R). Rosette mosaic virus infected all Spanish lines (Figure 4) during 2015A and 2015B, but its incidence was generally low (Table 10). Based on the general evaluation scale for viral diseases, all lines and varieties were categorised as highly resistant (HR). The lines that had below $10 \%$ disease incidence were categorised as very tolerant while the ones that had slightly over $10 \%$ were categorised as moderately resistant. Apart from ICGV SM 03590 and the 
Table 9. Germination and flowering periods of Spanish groundnut lines in the South Western Agro-Ecological Zone of Uganda during 2015A and 2015B.

\begin{tabular}{|c|c|c|c|c|c|c|c|c|c|c|}
\hline \multirow[t]{2}{*}{ Variety } & \multicolumn{5}{|c|}{ 20115A } & \multicolumn{5}{|c|}{ 2015B } \\
\hline & 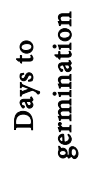 & 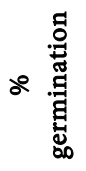 & 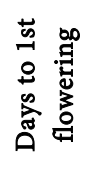 & 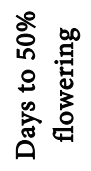 & 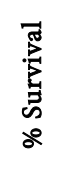 & 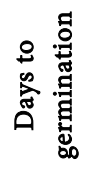 & ○ . & 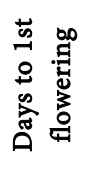 & 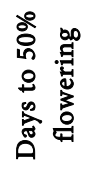 & 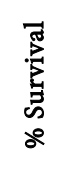 \\
\hline S4T & 13.0 & 80.2 & 37.3 & 43.3 & 75.5 & 14.0 & 75.2 & 20.3 & 28.3 & 88.9 \\
\hline ICGV SM 01502 & 13.3 & 79.3 & 36.8 & 42.0 & 73.8 & 15.0 & 78.3 & 19.3 & 29.0 & 89.2 \\
\hline ICGV SM 01504 & 13.3 & 75.2 & 36.3 & 41.0 & 72.2 & 14.3 & 78.8 & 19.8 & 28.0 & 88.5 \\
\hline ICGV SM 01510 & 13.5 & 64.5 & 37.8 & 41.5 & 82.0 & 14.3 & 77.1 & 20.3 & 28.5 & 93.7 \\
\hline ICGV SM 01514 & 13.3 & 73.1 & 37.8 & 45.0 & 80.3 & 14.0 & 86.2 & 22.0 & 30.0 & 90.2 \\
\hline ICGV SM 01515 & 13.5 & 75.1 & 37.0 & 41.5 & 75.4 & 14.5 & 79.8 & 20.5 & 29.0 & 85.1 \\
\hline ICGV SM 02501 & 15.5 & 39.5 & 39.3 & 48.0 & 87.6 & 20.5 & 64.2 & 16.8 & 29.8 & 84.6 \\
\hline ICGV SM 03590 & 13.8 & 51.9 & 39.3 & 46.5 & 75.0 & 15.8 & 43.1 & 21.0 & 29.5 & 94.2 \\
\hline ICGV SM 99555 & 13.0 & 86.3 & 37.0 & 41.0 & 74.4 & 14.0 & 83.7 & 20.5 & 28.8 & 89.6 \\
\hline ICGV SM 99568 & 13.3 & 77.7 & 36.3 & 40.8 & 74.4 & 14.3 & 75.4 & 20.5 & 29.0 & 87.4 \\
\hline Local & 17.0 & 88.6 & 34.7 & 43.3 & - & 12.7 & 66.7 & 17.0 & 32.2 & 55.0 \\
\hline $\operatorname{LSD}_{(\mathrm{P} \leq 0.05)}$ & 1.0 & 15.0 & 1.8 & 2.8 & NS & 1.9 & 13.0 & NS & NS & NS \\
\hline CV \% & 5.2 & 14.8 & 3.3 & 4.5 & 17.3 & 8.8 & 12.2 & 9.7 & 3.7 & 8.9 \\
\hline
\end{tabular}

Table 10. Groundnut leaf spot disease and Rosette Mosaic Virus (GRD) incidences on Spanish groundnut lines in the South Western Agro-Ecological Zone of Uganda during 2015A and 2015B.

\begin{tabular}{|c|c|c|c|c|c|c|}
\hline \multirow[t]{3}{*}{ Variety } & \multicolumn{3}{|c|}{ Leaf Spot Diseases } & \multicolumn{3}{|c|}{ Groundnut Rosette Mosaic Disease } \\
\hline & \multicolumn{2}{|c|}{$2015 \mathrm{~A}$} & \multirow{2}{*}{$\begin{array}{c}\text { 2015B } \\
\text { Incidence of LS } \\
\text { at harvest }(1-9)\end{array}$} & \multicolumn{2}{|c|}{$2015 \mathrm{~A}$} & \multirow{2}{*}{$\begin{array}{c}\text { 2015B } \\
\begin{array}{c}\text { \% Incidence at } \\
\text { harvest }\end{array}\end{array}$} \\
\hline & $\begin{array}{c}\text { Days to } 1^{\text {st }} \text { leaf } \\
\text { spot appearance }\end{array}$ & $\begin{array}{l}\text { Incidence of LS } \\
\text { at harvest }(1-9)\end{array}$ & & $\begin{array}{c}\% \text { Incidence } 8 \\
\text { WAP }\end{array}$ & $\begin{array}{l}\% \text { Incidence at } \\
\text { harvest }\end{array}$ & \\
\hline S4T & 52.3 & $6.6(S)$ & 4.9 (MS) & $6.5(\mathrm{HR})$ & $7.1(\mathrm{HR})$ & $6.0(\mathrm{HR})$ \\
\hline ICGV SM 01502 & 46.8 & $6.2(S)$ & $3.4(\mathrm{MR})$ & $5.5(\mathrm{HR})$ & $5.7(\mathrm{HR})$ & $7.3(\mathrm{HR})$ \\
\hline ICGV SM 01504 & 50.8 & $7.1(S)$ & $5.6(S)$ & 7.4 (HR) & $7.8(\mathrm{HR})$ & $6.5(\mathrm{HR})$ \\
\hline ICGV SM 01510 & 49.5 & $7.1(S)$ & 2.7 (MR) & 0.9 (HR) & $0.9(\mathrm{HR})$ & $6.9(\mathrm{HR})$ \\
\hline ICGV SM 01514 & 51.3 & 3.9 (MS) & $0.5(\mathrm{R})$ & 0.5 (HR) & $0.5(\mathrm{HR})$ & $5.9(\mathrm{HR})$ \\
\hline ICGV SM 01515 & 47.5 & $6.9(S)$ & 3.0 (MR) & 3.1 (HR) & 3.4 (HR) & $7.1(\mathrm{HR})$ \\
\hline ICGV SM 02501 & 49.3 & $1.6(\mathrm{MR})$ & $0.0(\mathrm{HR})$ & $0.3(\mathrm{HR})$ & $0.3(\mathrm{HR})$ & 3.5 (HR) \\
\hline ICGV SM 03590 & 49.0 & 2.0 (MR) & 4.5 (MR) & $13.3(\mathrm{R})$ & $14.0(\mathrm{R})$ & $1.8(\mathrm{HR})$ \\
\hline ICGV SM 99555 & 50.5 & $6.1(S)$ & $5.5(S)$ & 3.8 (HR) & $4.1(\mathrm{HR})$ & $6.8(\mathrm{HR})$ \\
\hline ICGV SM 99568 & 52.0 & $6.3(S)$ & 4.8 (MS) & $4.3(\mathrm{HR})$ & $4.4(\mathrm{HR})$ & $6.3(\mathrm{HR})$ \\
\hline Local & 58.5 & 5.3 (MS) & $5.2(\mathrm{MS})$ & $6.7(\mathrm{HR})$ & $6.9(\mathrm{HR})$ & $15.1(\mathrm{R})$ \\
\hline $\operatorname{LSD}_{(\mathrm{P} \leq 0.05)}$ & 3.8 & 0.9 & NS & 5.4 & 4.9 & 2.3 \\
\hline $\mathrm{CV} \%$ & 5.2 & 11.4 & 79.1 & 82.1 & 17.0 & 71.1 \\
\hline
\end{tabular}

Level of varietal resistance to leaf spot diseases: R—“Resistant" when the plant reaction to disease scored "1"; MR—“Moderately-resistant" (score 2 - 3); MS-"Moderately-susceptible" (score 4 - 5), S-“Susceptible" (score 6 - 7) and HS-"highly susceptible" (score 8 - 9). < $10 \%$ (highly resistant-HR); 11\% $30 \%$ (resistant-R); $31 \%-50 \%$ (moderately resistant $-\mathrm{MR}$ ) and $>50 \%$ (susceptible-S). 

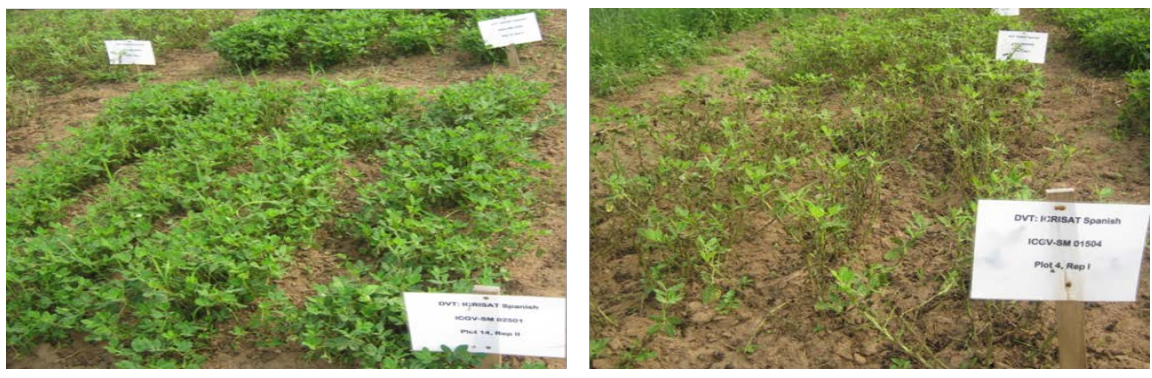

Figure 6. Leaf spot infection on Spanish resistant: ICGV SM 02501 (left) and susceptible: ICGV SM 01504 (right) lines in the South Western Agro-Ecological Zone of Uganda.

local variety, most Spanish lines were highly tolerant to rosette mosaic virus disease.

The Spanish lines had lower yields compared to the expected improved groundnut yields in Uganda. The yields varied across lines and seasons, but the 2015B (Table 11) crop, which received higher rainfall had slightly higher yields than the 2015A crop. On average, the Spanish lines had 16 - 41 pods per plant, but under favourable weather conditions, higher numbers of pods can be harvested per plant. The $2015 \mathrm{~B}$ season had higher yields than the 2015A, and most lines yielded over $1000 \mathrm{Kg} / \mathrm{ha}$ during this season. During 2015B, the best yielding variety was ICGV SM 99568 (1557 Kg/ha) followed by ICGV SM 01502 (1348 $\mathrm{Kg} / \mathrm{ha}$ ) and ICGV SM 01504 (1382 Kg/ha). ICGV 01510, ICGV SM 99555 and ICGV SM 01514 had moderately high yields. ICGV SM 02501 and ICGV SM 03590 had the lowest yields.

Overall, ICGV SM 99568 had the highest rate of germination and yield. The most leaf spot resistant line was ICGV SM 02501, but lines ICGV SM 01514, ICGV SM 03590, ICGV SM 01515 and ICGV SM 01502 reacted with varying levels of resistance during the two seasons. The best yielding lines were ICGV SM 99568, ICGV SM 01502, ICGV SM 01504, ICGV SM 01510, ICGV SM 99555 and ICGV SM 01514 (Table 11). The most rosette mosaic virus-disease susceptible, poorly germinating and high yielding lines were ICGV SM 03590, ICGV SM 02501 and ICGV SM 99568, respectively. Therefore, from this study the most promising Spanish lines identified for further evaluation and promotion in the SWAEZ were ICGV SM 01502, ICGV SM 99568, ICGV SM 01504, ICGV SM 01510, ICGV SM 99555, ICGV SM 01514 and ICGV SM 01515.

\section{Discussion}

In Uganda the Serenut groundnut genotypes were initially introduced around the 1990s to mitigate yield losses caused by the rosette mosaic virus disease [35]. These varieties have continued to display superior agronomic performances over the local varieties [36] [37]. While several varieties possess user preferred high grain quality attributes (preferred grain colour, size, ease of shelling, high nutrient and oil content), they have also been found to be high drought tolerant, moderate to high disease resistant, early maturing and high yielding in the SWAEZ. Although over 14 Serenut varieties had been released in Uganda by the 
Table 11. Yield performance of Spanish groundnut lines in the South Western Agro-Ecological Zone of Uganda during 2015A and $2015 \mathrm{~B}$.

\begin{tabular}{|c|c|c|c|c|c|c|c|c|c|c|c|}
\hline & $2015 A$ & & & & & & 2015B & & & & \\
\hline Variety & $\begin{array}{l}\text { Haulms } \\
\text { yield } \\
\text { (Kg/ha) }\end{array}$ & $\begin{array}{c}\text { Fresh pod } \\
\text { yield } \\
(\mathrm{Kg} / \mathrm{ha})\end{array}$ & $\begin{array}{c}\text { Pods per } \\
\text { plant }\end{array}$ & $\begin{array}{l}\text { Weight of } \\
100 \text { seeds } \\
\quad(\mathrm{g})\end{array}$ & $\begin{array}{c}\text { dry pod } \\
\text { yield } \\
(\mathrm{Kg} / \mathrm{ha})\end{array}$ & $\begin{array}{c}\text { Dry grain } \\
\text { yield } \\
(\mathrm{Kg} / \mathrm{ha})\end{array}$ & $\begin{array}{l}\text { Haulms } \\
\text { yield } \\
\text { (Kg/ha) }\end{array}$ & $\begin{array}{c}\text { Fresh pod } \\
\text { yield } \\
(\mathrm{Kg} / \mathrm{ha})\end{array}$ & $\begin{array}{l}\text { Weight of } \\
100 \text { seeds } \\
\text { (g) }\end{array}$ & $\begin{array}{c}\text { dry pod } \\
\text { yield } \\
(\mathrm{Kg} / \mathrm{ha})\end{array}$ & $\begin{array}{c}\text { Dry grain } \\
\text { yield } \\
(\mathrm{Kg} / \mathrm{ha})\end{array}$ \\
\hline S4T & 5848.0 & 3054.0 & 27.7 & 43.5 & 2065.0 & 712 & 7870.0 & 3815.0 & 29.0 & 1704.0 & 1097 \\
\hline ICGV SM 01502 & 3478.0 & 2815.0 & 16.4 & 46.0 & 1778.0 & 630 & 7407.0 & 5111.0 & 32.0 & 2889.0 & 1348 \\
\hline ICGV SM 01504 & 3870.0 & 2283.0 & 19.9 & 35.0 & 1492.0 & 577 & 5556.0 & 5259.0 & 32.8 & 2333.0 & 1382 \\
\hline ICGV SM 01510 & 3261.0 & 2065.0 & 18.3 & 51.5 & 1170.0 & 447 & 7500.0 & 4000.0 & 45.5 & 2000.0 & 1240 \\
\hline ICGV SM 01514 & 7391.0 & 4283.0 & 24.2 & 49.0 & 3248.0 & 682 & 9630.0 & 5222.0 & 34.0 & 2074.0 & 1207 \\
\hline ICGV SM 01515 & 5326.0 & 2620.0 & 21.5 & 42.0 & 1743.0 & 573 & 7278.0 & 5037.0 & 32.0 & 2074.0 & 1076 \\
\hline ICGV SM 02501 & 8217.0 & 4261.0 & 40.6 & 45.5 & 3253.0 & 632 & 11574.0 & 2481.0 & 40.5 & 926.0 & 403 \\
\hline ICGV SM 03590 & 11957.0 & 4228.0 & 40.9 & 29.5 & 3013.0 & 608 & 8889.0 & 1778.0 & 32.5 & 1111.0 & 339 \\
\hline ICGV SM 99555 & 5652.0 & 3196.0 & 15.6 & 43.0 & 2174.0 & 643 & 7315.0 & 4111.0 & 39.0 & 2111.0 & 1276 \\
\hline ICGV SM 99568 & 7391.0 & 3152.0 & 18.2 & 47.9 & 2183.0 & 749 & 7148.0 & 4667.0 & 42.3 & 2630.0 & 1557 \\
\hline $\operatorname{LSD}_{(\mathrm{P} \leq 0.05)}$ & 2862.2 & 1062.2 & 10.6 & 3.2 & 1082.7 & NS & NS & 1200.1 & 3.9 & 688.8 & 361.6 \\
\hline CV \% & 31.8 & 23 & 30.1 & 4.8 & 33.9 & 37.8 & 42.9 & 20 & 7.4 & 24 & 22.9 \\
\hline
\end{tabular}

end of 2011, most of these varieties have not been well adopted by the majority rural groundnut growers in SWAEZ due to limited access to the improved variety-seed and the associated production and marketing information [38] [39]. A study carried out in 2011 in the Northern and Eastern regions of Uganda, revealed that the adoption of improved groundnut varieties led to a $35 \%$ yield increase, and $41 \%$ reduction in production costs [37], among the respondents. Due to the low economic status of most of the rural groundnut farmers in Uganda and the Sub-Saharan African in general, efforts to increase their access to improved groundnut seed are needed to increase adoption, and thus solve production constraints of which the diseases [rosette mosaic virus [39], early leaf spot and late leaf spot [40]] are major. Many of the Serenut varieties have been reported to carry moderate to high levels of resistance and/or tolerance to the above major diseases [3] [34].

Whereas Serenut varieties have been reported to produce high yields (2500 $3700 \mathrm{~kg} / \mathrm{ha}$ ) in Eastern and Northern Uganda, the yield ranges of $583-1528$ $\mathrm{Kg} / \mathrm{ha}, 346-731 \mathrm{Kg} / \mathrm{ha}$ and $607-1047 \mathrm{Kg} / \mathrm{ha}$ harvested in 2014B, 2015A and 2015B, respectively, in the SWAEZ under rain-fed semi-arid conditions, signalled moderate yielding potential of Serenut when grown under proper disease and soil nutrient management practices. In addition to Serenut 2 and Serenut $3 \mathrm{R}$ that have been previously identified with high tolerance to rosette mosaic virus [34] [40], Serenut $1 \mathrm{R}$ was highly resistant to leaf spots, while Serenut $4 \mathrm{~T}$, Serenut $5 \mathrm{R}$ were highly resistant to rosette mosaic virus in the current study. Moreover, Serenut $4 \mathrm{~T}$, Serenut $5 \mathrm{R}$ and Serenut $6 \mathrm{~T}$ had higher yields than the 
highly disease resistant Serenut 2 and Serenut 3R in the SWAEZ across the three seasons. Although previous studies have shown that $\mathrm{S} 6 \mathrm{~T}$ is more resistant to GRD than S4T [15] [41], the current study results show that both lines: reacted with moderate-susceptibility to susceptibility to leaf spot during 2015A and B, had high resistant (HR) to GRD, but their yield ranges were not significantly different, though S4T had higher average yield in the SWAEZ. This study agrees with the previous findings, which have shown that S5R was highly resistant to GRD, moderately resistant to leaf spot diseases and high yielding [42]. The agronomic attributes plus the highly preferred grain colour and size of S5R identified it as the most suitable Serenut variety for the SWAEZ.

The tendency of late leaf spot disease to develop towards or during the reproductive and pod formation stages, has been found to cause major foliage damages that lead to over $50 \%$ yield losses [11]. The variation of leaf spot disease incidences on plants across season/environment in the current study, influenced the resistance gene expression in the Serenut varieties most of which reacted with varying levels of resistance and susceptibility across seasons. Although higher leaf spot incidences occurred during the 2015A, Serenut 1, Serenut 2 and Serenut 3 displayed resistance $(R)$, resistance $(R)$ and moderate-resistance (MR), respectively, while in 2015B, all the three varieties displayed moderate-resistance (MR). Serenut 2 and Serenut 3 were highly resistant (HR) to GRD during 2015A and 2015B in the SWAEZ. Varieties that react with high levels of resistance to the GRD and leaf spots, which cause major yield losses of groundnut in the SWAEZ are the best to be adopted by farmers if these performances positively correlated with yield.

The initial inconsistences in the agronomic performances of the AGRA red lines across season (2014B, 2015A and 2015B) were probably influenced by environmental factors of which rainfall and temperature were major. While the control variety (Serenut 1) showed consistent earliness in days to germination and flowering during the three seasons, the AGRA red lines took longer to germinate and flower. The crops grown during the long rain seasons (2014B and 2015B) germinated earlier than the crops grown in the short rainy season (2015A). Although there was no consistent trend in days to flowering of AGRA red lines versus Serenut 1 (control), the 2015B crop flowered earlier than the rest of the previous seasons. Plant germination ranged from significantly high to moderate and moderately-high during 2014B, 2015A and 2015B, respectively, but the reason for the moderate level of plant germination during 2015A could not be ascertained. At maturity, the rate of groundnut plant survival in the SWAEZ was high $(95.0 \%-100 \%$ and $76.3 \%-91.9 \%)$ during $2014 \mathrm{~B}$ and $2015 \mathrm{~A}$, respectively. All test AGRA red lines reacted with moderately-resistance (MR) to the leaf spot diseases during 2015A, but in 2015B, lines SGV 99048, SGV 99046, SGV 99032, SGV 99065 were resistant (R). The slight change in the level of varietal resistance to the leaf spot infections under the two seasons may have been influenced by genetic and environmental factors $(G \times E)$ [26] [27] [43]. The combination of high levels of resistance to leaf spots and mosaic rosette virus disease (GRD) in the AGRA red lines can mitigate the losses associated with the 
above diseases [44], leading to significant groundnut yield gains and production increase in the SWAEZ. Because there was probably no significant effect of the two diseases on the agronomic performances of the lines, the yields were attributed to varietal genetic abilities. Apart from inconsistent yield trends of AGRA red lines based on haulm weight, pods per plant, fresh pod weight, 100 seed weight and dry grain weight across variety and season, the high performance of SGV 99046, SGV 990241 and SGV 99064 based on the average marketable dry grain yields led to the identification of these lines for the zone. Additionally, the yields of lines SGV 99048, SGV 99019 and SGV 99032 were not significantly different from the above three lines, implying that they can also be well adapted to the SWAEZ. The correlation coefficients derived from the 100-seed weights and actual grain yields $(r=0.503)$; pods per plant and grain yields $(r=0.267)$ indicated linear positive relationships.

Apart from ICGV SM 02501 and ICGV SM 03590, most of the Spanish lines germinated early (13 - 16 DAP) with moderate to high germination rates $(64.5 \%$ - 86.3\%), but the days to flowering significantly varied across genotype during 2015A. While, there were no significant differences in plant survival rates among the Spanish lines, the 2015B crop had higher plant survival rates than the 2015A season. The effects of environmental variation on leaf spot disease incidences caused the Spanish lines to react with different levels of resistance $(\mathrm{R})$ and susceptibility (S) during 2015A and B, but most Spanish lines reacted with moderate-susceptibility (MS) and susceptibility (S). The ability of ICGV SM 02501 to reach with MR-R to leaf spots and HR to GRD during the 2015A and 2015B, respectively, indicated that this line was suitable for the SWAEZ conditions. Elsewhere, high yielding Spanish genotypes with resistance to leaf spot diseases have been developed [45], but most Spanish lines that were either HR or R to GRD in the current study, unfortunately were either MS or $S$ to the leaf spot diseases. Therefore, the Spanish lines tested in the current study were found to be suitable for environments that are prone to GRD but free of the leaf spot pathogens. The low yield performance of the Spanish groundnut lines in the SWAEZ was probably associated with the higher leaf spot disease incidences during 2015A, during which most responded with either moderate-susceptibility (MS) or susceptibility (S) to leaf spot diseases. The negative correlation coefficients between leaf spot incidences and yields $(r=-0.127)$, indicated that under conditions where disease pressure was high, the yield performances of the lines were low. Moreover, a slight reduction in leaf spot incidences on the Spanish lines during 2015B resulted in high yields, thus the low positive correlation $(r=0.035)$ indicating that the lower the disease, the high was the yield response.

\section{Conclusion}

In conclusion, the AGRA red and Spanish groundnut lines, expressed high adaptability potential and disease tolerance under the SWAEZ conditions implying that they are likely to perform well if adopted by farmers. Similarly, the Serenut varieties expressed superiority over the local variety in terms of disease 
tolerance and earliness. While most improved varieties yielded slightly better than the local variety, they did not yield as potentially expected. While leaf spot and rosette mosaic virus diseases are the most important groundnut diseases in Uganda [46], this study agreed that leaf spots (early and late leaf spot diseases) caused major foliage destruction [47], especially during the reproductive and pod development stages. Thus, severe leaf spot incidences at reproductive and pod development stages may be the major contributor to the high groundnut yield losses than the rosette mosaic virus disease (GRD) in the SWAEZ. The late leaf spot disease tends to develop later in the season, but becomes severe within a short period hence destroying all foliage and other aerial plant parts. Rosette mosaic virus was generally low during the entire experimenting period on station, but expressed itself in two types of green and yellow rosette viruses. This study determined that the test AGRA red and Spanish lines were highly tolerant to rosette mosaic virus disease. SGV lines 99241, 99046, 99064, 99048, 99019 and 99032 performed better, while Serenut 5R was the most promising early and virus tolerant variety. Apart from Serenut 1; Serenut 2, 3R, 4R, 5R and $6 \mathrm{~T}$ also displayed very high levels of tolerance to rosette mosaic virus disease in the SWAEZ. The combination of MR-R and HR in the AGRA red lines and Serenut varieties to leaf spots and rosette mosaic virus, respectively, indicated an effective control measure of the major groundnut disease problems in the zone. The integration of moderate-resistance to high disease resistance, high drought tolerance and high yielding potential in several Serenut, AGRA red and Spanish lines can enhance groundnut production if proper agronomic management practices and timely planting are applied.

\section{Acknowledgements}

The project was funded by the Government of Uganda. Improved groundnut lines were kindly provided by Dr. Okello David Kalule at the National Semi-Arid Agricultural Research Institute (NaSARRI) Soroti, National Agricultural Research Organisation, Uganda. Thanks to the technical support by Maggiore Kyomugisha at Mbarara Zonal Agricultural Research and Development Institute (MBAZARDI) for setting up and managing the field experiments.

\section{Funding}

This work was funded by the Government of Uganda through the National Agricultural Research Organisation (NARO) research and development projects.

\section{Conflicts of Interest}

The authors declare that they have no conflict.

\section{References}

[1] Atasie, V.N., Akinhanmi, T.F. and Ojiodu, C.C. (2009) Proximate Analysis and Physico-Chemical Properties of Groundnut (Arachis hypogaea L.). Pakistan Journal of 
Nutrition, 8, 194-197. https://doi.org/10.3923/pjn.2009.194.197

[2] Vanham, D., Mekonnen, M.M. and Hoekstra, A.Y. (2020) Treenuts and Groundnuts in the EAT-Lancet Reference Diet: Concerns Regarding Sustainable Water Use. Global Food Security, 24, Article ID: 100357. https://doi.org/10.1016/j.gfs.2020.100357

[3] Savage, G.P. and Keenan, J.I. (1994) The Composition and Nutritive Value of Groundnut Kernels. In: Smartt, J., Ed., The Groundnut Crop, Springer, Dordrecht, 173-213. https://doi.org/10.1007/978-94-011-0733-4 6

[4] Achola, E., Tukamuhabwa, P., Adriko, J., Edema, R., Mwale, S.E., Gibson, P., Naveen, P., Okul, V., Michael, D. and Okello, D.K. (2017) Composition and Variation of Fatty Acids among Groundnut Cultivars in Uganda. African Crop Science Journal, 25, 291-299. https://doi.org/10.4314/acsj.v25i3.3

[5] Muzoora, S., Khaitsa, M.L., Bailey, H., and Vuzi, P. (2017) Status on Aflatoxin Levels in Groundnuts in Uganda. Pan African Medical Journal, 27, 11.

[6] Nambiar, P.T.C., Rao, M.R., Reddy, M.S., Floyd, C., Dart, P.J. and Willey, R.W. (1982) Nitrogen Fixation by Groundnut (Arachis hypogea Ea) in Intercropped and Rotational Systems. 647-652.

[7] Chaudhary, S., Chaturvedi, S. and Dhyani, V.C. (2020) Effect of Crop Diversification and Residue Management Techniques on Yield Attributes, Yield and Soil Nutrient. International Journal of Chemical Studies, 8, 1107-1111. https://doi.org/10.22271/chemi.2020.v8.i2q.8915

[8] Bado, B.V., Bationo, A., Lompo, F., Traore, K., Sedogo, M.P. and Cescas, M.P. (2012) Long Term Effects of Crop Rotations with Fallow or Groundnut on Soil Fertility and Succeeding Sorghum Yields in the Guinea Savannah of West Africa. In: Bationo, A., Waswa, B., Kihara, J., Adolwa, I., Vanlauwe, B. and Saidou, K., Eds., Lessons Learned from Long-Term Soil Fertility Management Experiments in Africa, Springer, Dordrecht, 27-40. https://doi.org/10.1007/978-94-007-2938-4 2

[9] Gaskin, J.W., Speir, R.A., Harris, K., Das, K.C., Lee, R.D., Morris, L.A. and Fisher, D.S. (2010) Effect of Peanut Hull and Pine Chip Biochar on Soil Nutrients, Corn Nutrient Status, and Yield. Agronomy Journal, 102, 623-633.

https://doi.org/10.2134/agronj2009.0083

[10] Page, W.W., Busolo-Bulafu, C.M., vander Merwe, P.J.A. and Chancellor, T.C.B. (2002) Groundnut Manual for Uganda: Recommended Groundnut Production Practices for Smallholder Farmers in Uganda. Natural Resources Institute, Chatham, UK, 1-12.

[11] Anco, D.J., Thomas, J.S., Jordan, D.L., Shew, B.B., Monfort, W.S., Mehl, H.L., Small, I.M., Wright, D.L., Tillman, B.L., Dufault, N.S. and Hagan, A.K. (2020) Peanut Yield Loss in the Presence of Defoliation Caused by Late or Early Leaf Spot. Plant Disease, 104, 1390-1399. https://doi.org/10.1094/PDIS-11-19-2286-RE

[12] USDA (2019) World Agricultural Production U.S. Department of Agriculture Foreign Agricultural Service/Office of Global Analysis International Production Assessment Division (IPAD).

https://downloads.usda.library.cornell.edu/usda-esmis/files/5q47rn72z/0g354t050/r 494vz32w/production.pdf

[13] FAOSTAT (2019) Food and Agriculture Data. http://www.fao.org/faostat/en/\#data/QC/visualize

[14] Ntakyo, P., Kankwatsa, P., Muzira, R., Kemigabo, C., Lagu, C. and Nabasumba, D. (2012) Farming Systems and Livelihood Analysis in South Western Uganda 
Agro-Ecological Zone. Technical Report, Mbarara Zonal Agricultural Research and Development Institute, Uganda, 92.

[15] Okello, D.K., Ugen, M.A., Odong, T.L., Monyo, E., Akpo, E., Okori, P. and Deom, C.M. (2017) Current Status of Groundnut Improvement in Uganda. InterDrought-V, Hyderabad, 117.

[16] Akpo, E., Muricho, G., Lukurugu, G.A., Opie, H., Ojiewo, C.O. and Varshney, R. (2020) Legume Seed Production for Sustainable Seed Supply and Crop Productivity: Case of Groundnut in Tanzania and Uganda. Journal of Crop Improvement, 34, 518-539. https://doi.org/10.1080/15427528.2020.1740368

[17] Daudi, H., Shimelis, H., Laing, M., Okori, P. and Mponda, O. (2018) Groundnut Production Constraints, Farming Systems, and Farmer-Preferred Traits in Tanzania. Journal of Crop Improvement, 32, 812-828. https://doi.org/10.1080/15427528.2018.1531801

[18] Dalla, A.A., Vihi, S.K., Jesse, B. and Tor, L.G. (2020) Cost and Returns Analysis of Groundnut Production in Qua'an Pan Local Government Area of Plateau State, Nigeria. Asian Journal of Research in Crop Science, 5, 31-40. https://doi.org/10.9734/ajrcs/2020/v5i330098

[19] Subrahmanyam, P., McDonald, D., Waliyar, E., Reddy, L.J., Nigam, S.N., Gibbons, R.W., Ramanatha Rao, V., Singh, A.K., Pande, S., Reddy, P.M. and Subba Rao, P.V. (1995) Screening Methods and Sources of Resistance to Rust and Late Leaf Spot of Groundnut. International Crops Research Institute for the Semi-Arid Tropics, Patancheru, Information Bulletin No. 47.

[20] Mukibi, J.K. (1982) Effect of Intercropping on Some Diseases of Beans and Groundnuts: Summary. In Intercropping: Proceedings of the Second Symposium on Intercropping in Semi-Arid Areas, Morogoro, 4-7 August 1980, 168 p.

[21] McDonald, D., Subrahmanyam, P., Gibbons, R.W. and Smith, D.H. (1985) Early and Late Leaf Spots of Groundnut. International Crops Research Institute for the Semi-Arid Tropics, Patancheru, Information Bulletin No. 21.

[22] Appiah, A.S., Offei, S.K., Tegg, R.S., and Wilson, C.R. (2016) Varietal Response to Groundnut Rosette Disease and the First Report of Groundnut Ring Spot Virus in Ghana. Plant Disease, 100, 946-952. https://doi.org/10.1094/PDIS-07-15-0838-RE

[23] Bua, B. and Opio, M. (2014) Variability in Reactions of Groundnuts Varieties to Groundnut Rosette Virus Isolates from Uganda. American Journal of Experimental Agriculture, 4, 541-549.

[24] Okello, D.K., Biruma, M. and Deom, C.M. (2010) Overview of Groundnuts Research in Uganda: Past, Present and Future. African Journal of Biotechnology, 9, 6448-6459.

[25] Kakeeto, R., Melis, R., Biruma, M. and Sibiya, J. (2020) Gene Action Governing the Inheritance of Drought Tolerance and Selected Agronomic Traits in Ugandan Groundnut (Arachis hypogaea L.) Lines under Drought Environment. Euphytica, 216, Article No. 1. https://doi.org/10.1007/s10681-019-2539-6

[26] Kakeeto, R., Sibiya, J., Melis, R. and Biruma, M. (2019) Farmers' Perceptions of Drought and Other Production Constraints, Drought Mitigation Options and Their Implications for Groundnut Breeding in Uganda. Indian Journal of Agricultural Research, 53, 45-50. https://doi.org/10.18805/IJARe.A-337

[27] Kakeeto, R., Baguma, S.D., Subire, R., Kaheru, J., Karungi, E. and Biruma, M. (2019) Genetic Variation and Heritability of Kernel Physical Quality Traits and Their Association with Selected Agronomic Traits in Groundnut (Arachis hypogeae) Geno- 
types from Uganda. African Journal of Agricultural Research, 14, 597-603. https://doi.org/10.5897/AJAR2018.13789

[28] Abady, S., Shimelis, H., Janila, P. and Mashilo, J. (2019) Groundnut (Arachis hypogaea L.) Improvement in Sub-Saharan Africa: A Review. Acta Agriculturae Scandinavica, Section B-Soil \& Plant Science, 69, 528-545.

https://doi.org/10.1080/09064710.2019.1601252

[29] Molotoks, A., Smith, P. and Dawson, T.P. (2021) Impacts of Land Use, Population, and Climate Change on Global Food Security. Food and Energy Security, 10, e261. https://doi.org/10.1002/fes3.261

[30] Mau, Y.S. and Ndiwa, A.S.S. (2018) Field Evaluation of Late Leaf Spot and Leaf Rust Resistance and the Associated Yield Losses in Indonesian Groundnut Genotypes. Asian Journal of Plant Sciences, 17, 134-141. https://doi.org/10.3923/ajps.2018.134.141

[31] Waliyar, F., Kumar, P.L., Ntare, B.R., Monyo, E., Nigam, S.N., Reddy, A.S. and Diallo, A.T. (2007) A Century of Research on Groundnut Rosette Disease and Its Management. International Crops Research Institute for the Semi-Arid Tropics, Patancheru, Information Bulletin No. 75.

[32] Freedman, D., Pisani, R. and Purves, R. (2007) Statistics (International Student Edition). 4th Edition, WW Norton \& Company, New York, 141-157.

[33] Luo, M., Dang, P., Bausher, M.G., Holbrook, C.C., Lee, R.D., Lynch, R.E. and Guo, B.Z. (2005) Identification of Transcripts Involved in Resistance Responses to Leaf Spot Disease Caused by Cercosporidium personatum in Peanut (Arachis hypogaea). Phytopathology, 95, 381-387. https://doi.org/10.1094/PHYTO-95-0381

[34] Kayondo, S.I., Rubaihayo, P.R., Ntare, B.R., Gibson, P.T., Edema, R., Ozimati, A. and Okello, D.K. (2014) Genetics of Resistance to Groundnut Rosette Virus Disease. African Crop Science Journal, 22, 21-30.

[35] Busolo-Bukafu, C.M. (2004) Development of Groundnut Rosette Disease and Vector Resistant Varieties. Uganda Journal of Agricultural Sciences, 9, 574-577.

[36] Jelliffe, J.L., Bravo-Ureta, B.E., Deom, C.M. and Okello, D.K. (2018) Adoption of High-Yielding Groundnut Varieties: The Sustainability of a Farmer-Led Multiplication-Dissemination Program in Eastern Uganda. Sustainability, 10, 1597. https://doi.org/10.3390/su10051597

[37] Kassie, M., Shiferaw, B. and Muricho, G. (2011) Agricultural Technology, Crop Income, and Poverty Alleviation in Uganda. World development, 39, 1784-1795. https://doi.org/10.1016/j.worlddev.2011.04.023

[38] Mugisha, J., Ogwal-o, R., Ekere, W. and Ekiyar, V. (2004) Adoption of IPM Groundnut Production Technologies in Eastern Uganda. African Crop Science Journal, 12, 383-391. https://doi.org/10.4314/acsj.v12i4.27900

[39] Naidu, R.A., Kimmins, F.M., Holt, J., Robinson, D.J., Deom, C.M. and Subrahmanyam, P. (1999) Spatiotemporal Separation of Groundnut Rosette Disease Agents. Phytopathology, 89, 934-941. https://doi.org/10.1094/PHYTO.1999.89.10.934

[40] Mohammed, K.E., Afutu, E., Odong, T.L., Okello, D.K., Nuwamanya, E., Grigon, O. and Okori, P. (2018) Assessment of Groundnut (Arachis hypogaea L.) Genotypes for Yield and Resistance to Late Leaf Spot and Rosette Diseases. Journal of Experimental Agriculture International, 21, 1-13.

[41] Okello, D.K., Deom, C.M., Puppala, N., Monyo, E. and Bravo-Ureta, B. (2018) Registration of 'Serenut 6T' Groundnut. Journal of Plant Registrations, 12, 43-47. https://doi.org/10.3198/jpr2017.03.0016crc 
[42] Okello, D.K., Deom, C.M., Puppala, N., Monyo, E. and Bravo-Ureta, B. (2016) Registration of 'Serenut 5R' Groundnut. Journal of Plant Registrations, 10, 115-118. https://doi.org/10.3198/jpr2015.07.0041crc

[43] Chaudhari, S., Khare, D., Patil, S.C., Sundravadana, S., Variath, M.T., Sudini, H.K., Manohar, S.S., Bhat, R.S. and Pasupuleti, J. (2019) Genotype $\times$ Environment Studies on Resistance to Late Leaf Spot and Rust in Genomic Selection Training Population of Peanut (Arachis hypogaea L.). Frontiers in Plant Science, 10, 1338. https://doi.org/10.3389/fpls.2019.01338

[44] Kankam, F., Kojo, K.Y. and Addai, I.K. (2020) Evaluation of Groundnut (Arachis Hypogea L.) Mutant Genotypes for Resistance against Major Diseases of Groundnut. Pakistan Journal of Phytopathology, 32, 61-69. https://doi.org/10.33866/phytopathol.032.01.0554

[45] Ganesan, K.N., Kumari, B.M., Veerabadhiran, P., Binodh, A.K., Devanand, P.S. Pushpam, R., Punitha, D., Maruthachalam, S., Venugopal, S., Prabakaran, N.K. and Ganesamurthy, K. (2019) A New High Yielding Spanish Bunch Groundnut Variety BSR 2. Electronic Journal of Plant Breeding, 10, 1495-1500.

https://doi.org/10.5958/0975-928X.2019.00192.3

[46] Okello, D.K., Akello, L.B., Tukamuhabwa, P., Odong, T.L., Adriko, J. and Deom, C. M. (2014) Groundnut Rosette Disease Symptoms Types Distribution and Management of the Disease in Uganda. African Journal of Plant Science, 8, 153-163. https://doi.org/10.5897/AJPS2014.1164

[47] Krishna, G.K., Pande, S. and Narayana, J.R. (2001) Control of Late Leaf Spot of Groundnut (Arachis hypogaea) by Extracts from Non-Host Plant Species. Journal of Plant Pathology, 17, 264-270. 